\title{
O Ocidente Medieval segundo a historiografia brasileira
}

Ana Carolina Lima Almeida e Clínio de Oliveira Amaral

\section{(2) OpenEdition}

1 Journals

\section{Edição electrónica}

URL: http://journals.openedition.org/medievalista/1051

DOI: 10.4000/medievalista.1051

ISSN: 1646-740X

\section{Editora}

Instituto de Estudos Medievais - FCSH-UNL

\section{Refêrencia eletrónica}

Ana Carolina Lima Almeida e Clínio de Oliveira Amaral, «O Ocidente Medieval segundo a historiografia brasileira», Medievalista [Online], 4 | 2007, posto online no dia 05 março 2021, consultado o 25 março 2021. URL: http://journals.openedition.org/medievalista/1051 ; DOI: https://doi.org/10.4000/ medievalista.1051

\section{(c) (†) \&)}

Mediavalista está licenciado com uma Licença Creative Commons - Atribuição-NãoComercial 4.0 Internacional 


\section{O Ocidente Medieval segundo a historiografia brasileira ${ }^{1}$}

\section{Ana Carolina Lima Almeida \\ bolsista da CAPES \\ Clínio de Oliveira Amaral}

bolsista do CNPq e bolsista sanduíche na França, EHESS, da CAPES

Expor a forma como a historiografia brasileira estuda a idade média, sem dúvida, traz problemas significativos devido às dimensões continentais do Brasil, à falta de integração entre os centros de pesquisa e à carência de uma política de publicação das teses e dissertações que são defendidas no país. Por essas e outras razões, adverte-se que a elaboração de um balanço de toda produção sobre história medieval no Brasil é um trabalho que só pode ser realizado a longo prazo e com a participação de um número suficiente de pesquisadores uma vez que implica em deslocamentos para os centros de produção de teses e dissertações. No entanto, sabe-se que foi realizado, recentemente, um catálogo ${ }^{2}$ das teses e dissertações defendidas no Brasil.

\footnotetext{
${ }^{1}$ Ana Carolina Lima Almeida (bolsista da CAPES) e Clínio de Oliveira Amaral (bolsista do CNPq e bolsista sanduíche na França, EHESS, da CAPES) são pós-graduandos em História Social na Universidade Federal Fluminense, UFF, Brasil e atuam como pesquisadores colaboradores do Scriptorium - Laboratório de Estudos Medievais e Ibéricos da Universidade Federal Fluminense, UFF. Registra-se que os autores elaboraram o texto entre Paris, Lisboa e Niterói e não tiveram como acessar grande parte do material disponível sobre idade média produzido pela historiografia brasileira. Por esse motivo, declare-se que o panorama da historiografia brasileira, aqui apresentado, foi apenas um esboço de um mapeamento que, realizado de forma integral, é extremamente amplo. Devido à impossibilidade de consultar as bibliotecas das universidades dos outros estados, optou-se por trabalhar com as bases de dados on-line, as quais representam uma pequena parcela produção dessas instituições, pois as mesmas estão em processo de implementação, disponibilizando para consulta apenas as dissertações e as teses mais recentes.

2 José Rivair Macedo, Os estudos medievais no Brasil: catálogo de teses e dissertações. Porto Alegre: EDUFRGS, 2003. Devido às condições em que este texto foi elaborado, Cf. nota 1, não foi possível consultar o livro aqui indicado. Porém, trata-se de um importante instrumento para se discutir a historiografia medieval brasileira.
} 
Apresentar-se-ão, da forma mais exaustiva possível, dentro das condições e que se elaboraram esta exposição ${ }^{3}$, as principais produções a partir dos anos 90 relacionando-as aos grandes vetores da historiografia contemporânea. Para a elaboração desse panorama historiográfico, foram feitas algumas escolhas, dentre as quais se destaca a predileção por mencionar os trabalhos relativos à idade média ibérica e o fato de que se estabeleceu como critério o estudo das principais teses e dissertações. Além disso, optou-se pela produção da pós-graduação dos centros de estudos em idade média das universidades públicas brasileiras. Sublinha-se ainda que não foram considerados os trabalhos sobre idade média produzidos por outros campos do saber.

Serão analisadas as produções da Universidade Federal Fluminense (UFF) pelo fato de que nessa universidade existe o maior centro de pesquisa sobre idade média ibérica do país, coordenado pela professora Vânia Leite Fróes ${ }^{4}$; da Universidade de São Paulo (USP) por ser a universidade com mais longa tradição de elaboração de trabalhos na área de medieval, bem como por ter sido, até meados da década de 80 , a instituição que mais formou pesquisadores nessa área; da Universidade Estadual de Campinas (UNICAMP), atualmente, considerada como um centro de excelência na produção historiográfica e por ter importantes trabalhos na área da hagiografia medieval; da Universidade de Brasília (UNB), que tem um papel importante na estruturação e propagação de estudos relativos à idade média na região Centro-Oeste do Brasil e, por último, da Universidade Federal do Rio Grande do Sul (UFRGS), na qual se encontra uma produção de teses e dissertações em idade média no Sul do país.

Adverte-se que a análise das produções de cada universidade está relacionada ao conhecimento bibliográfico e à possibilidade de pesquisa oferecida pelas bibliotecas online dessas universidades. Ressalta-se que a ênfase dada à UFF deve-se à maior intimidade dos autores deste texto com essa produção, mas isso, de forma alguma, estabelece algum tipo de hierarquia ou juízo de valor quanto ao que é elaborado nas

\footnotetext{
${ }^{3}$ Cf. Nota 1 .

${ }^{4}$ Disponível em: $<$ http://buscatextual.cnpq.br/buscatextual/index.jsp $>$ Acesso em: 27 janeiro 2008. Nesse endereço pode ser encontradas informações sobre a produção dessa pesquisadora.
} 
demais instituições. Acrescenta-se ainda que todas essas universidades são bem avaliadas pela $\mathrm{CAPES}^{5}$.

A UFF abriga uma parte considerável das pesquisas realizadas no estado do Rio de Janeiro. Nessa universidade ${ }^{6}$, desde o final dos anos 80 , começaram a surgir pesquisas sobre idade média em torno das investigações organizadas por Froés ${ }^{7}$ que fundou um grupo de pesquisa cujo propósito era promover investigações sobre essa temática ${ }^{8}$. Atualmente, o Scriptorium - Laboratório de Estudos Medievais e Ibéricos, coordenado por Fróes, conta com duas grandes linhas de pesquisa em torno das quais uma série de teses e dissertações foram elaboradas.

O mais antigo campo de investigação está relacionado aos estudos do imaginário e poder político na idade média. Fazem parte dessa linha de pesquisa temas, como, por exemplo, as discussões sobre a função do poder régio, as suas formas de exibição, os mecanismos de produção de memória social, os debates sobre a sacralidade régia, a relação entre história de gênero e as suas relações com o campo da nova história política. Em relação a essa linha de pesquisa, deve-se mencionar a grande influência francesa, sobretudo, através da Écoles des Annales e da Nouvelle Historie. Além dessa influência, destaca-se o diálogo bibliográfico com os autores portugueses e espanhóis.

As investigações sobre o poder político são provenientes do trabalho de Fróes em cuja tese $^{9}$ defendeu que a figura do rei deve ser compreendida como uma referência identitária. Segundo a autora, o rei é um topos e o seu Paço é um lugar de ordenamento

\footnotetext{
${ }^{5}$ CAPES (Coordenação de Aperfeiçoamento de Nível Superior). Essa instituição realiza trianualmente

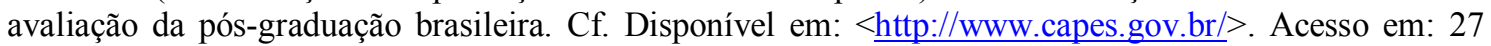
janeiro 2008.

${ }^{6}$ Para acessar os catálogos on-line. Cf. Disponível em:

$<$ http://www.bdtd.ndc.uff.br/tde busca/index.php $>$. Acesso em 27 janeiro 2008.

7 Vânia L. Fróes, Espaço e Sociedade em Gil Vicente: contribuição para um estudo do imaginário português (1502 - 1536). São Paulo, 1986. Tese (Doutorado em História Social) - Faculdade de Filosofia, Letras e Ciências Humanas, Universidade de São Paulo, São Paulo, 1986.; Idem, Era no Tempo do Rei - estudo sobre o ideal do rei e das singularidades do imaginário português no final da Idade Média. Niterói, 1995. Tese (Titular em História Medieval) - Instituto de Ciências Humanas e Filosofia, Universidade Federal Fluminense, Niterói, 1995.

${ }^{8}$ Cf. Disponível em <http://dgp.cnpq.br/buscaoperacional/detalhepesq.jsp?pesq=0984686980830672> Acesso em: 27 janeiro 2008.

${ }^{9}$ Cf. Nota 5.
} 
do mundo e do reino. Para melhor esclarecer a relação entre o Paço régio e a sociedade portuguesa dos séculos XV e XVI, ela formulou o conceito de discurso do Paço ${ }^{10}$.

Dentro dessa perspectiva, o Paço régio foi compreendido como uma área, um eixo organizador que estabelece um padrão de conduta e uma cosmologia. Portanto, existe uma relação entre proximidade e distância que define hierarquias de tempos, lugares e pessoas. Do ponto de vista simbólico, ele se constitui como uma ordem que paira sobre a sociedade ao mesmo tempo que a hierarquiza segundo padrões de condutas definidos dentro da corte régia ${ }^{11}$.

A partir da década de 90, houve a produção de vários trabalhos cujos conteúdos abordam o imaginário político como uma forma de se discutir a idade média. Autores, como, por exemplo, Nieto Soria ${ }^{12}$, Pacaut $^{13}$, Gunée ${ }^{14}$, Garcia-Pelayo ${ }^{15}$ exerceram influências sobre os trabalhos dessa linha de pesquisa.

\footnotetext{
${ }^{10}$ Vânia L. Fróes, Espaço e... op. cit. A autora trabalhou com a temática ligada ao imaginário político português em outros artigos. Cf. Idem. Identificação de um país. Ensaios sobre as origens de Portugal de José Mattoso. Estudo crítico da obra. Revista de Estudos Históricos Identidade Nacional IUPERJ. Rio de Janeiro: IUPERJ, Vol. 1, no. 2, pp. 279-304, [s.m.], 1988.; Idem, Evolução das representações e da pedagogia do ofício de rei em Portugal Medieval. Convergência Lusíada. Revista do Real Gabinete Português. Rio de Janeiro: Editorial Nórdica, nº 15, p. 23-31, [s.m.], 1998.; Idem. Teatro como missão e espaço de encontro de culturas. Actas do congresso internacional de História e Missionação Portuguesa e encontros de culturas. Braga: Universidade Católica de Lisboa/Universidade Clássica de Lisboa, 1993, Vol. 3, pp. 254-289.; Idem (org.). Atas do III Colóquio Luso-Brasileiro - Viagens e viajantes, almocreves, bandeirantes, tropeiros e navegantes. Niterói/Rio de Janeiro: Scriptorium - Laboratório de Estudos Medievais e Ibéricos/ FAPERJ, 2001.

${ }^{11}$ Sobre a definição do conceito de discurso do Paço, Cf. Vânia L. Fróes Espaço e... op. cit., p. 125.;Idem, Le Cardinal du Portugal : célébration de la vie et mémoire de la morte à Florence au "Quattrocent"o. A Igreja e o clero português no contexto europeu. Lisboa: Universidade Católica: Centro de Estudos de História Religiosa, 2005, pp. 257-266.

${ }^{12}$ Especificamente os trabalhos a seguir: José Manuel Nieto Soria. Fundamentos ideológicos del poder real en Castilla (XIII - XVI). Madrid: Eudema, 1988.; Idem, Ceremonias de la realeza. Propaganda y legitimación en la Castilla Trastámara. Madrid: Nerea, 1993. Nesse segundo livro, rechaça a argumentação de Ruiz sobre a inviabilidade do conceito de sacralidade monárquica para a Espanha. Para ler a posição de Ruiz sobre o conceito de sacralidade na Espanha. Cf. Teofilo F Ruiz, "Une royauté sans sacre : la monarchie castillane du Bas Moyen Age". Annales Économies Sociétés Civilisations. Paris : C.N.R.S et E.H.E.S.S, Année $39^{\mathrm{e}}, \mathrm{n}^{\circ} 3$, pp.429-453, mai-juin 1984, pp. 429-430. Vale destacar, portanto, que os autores brasileiros acompanharam esse debate e se posicionam conforme Nieto Soria.

${ }_{13}^{13}$ Marcel Pacaut, Les structures politiques de l'Occident médiéval. Paris : Ed. Armand Colin, 1969.

${ }^{14}$ Bernard Guenée et Jacques Heers, L'Occident aux XIV et XV siècles. Paris : PUF, 1963.

${ }^{15}$ ManuelGarcia-Pelayo, Mitos y símbolos políticos. Madrid: Taurus, 1964.
} 
Os conceitos de imaginário ${ }^{16}$, memória ${ }^{17}$, maravilhoso ${ }^{18}$ foram importantes na pesquisa de Miranda ${ }^{19}$, que analisou o imaginário português entre os séculos XIII e XIV por meio do estudo do maravilhoso de Nossa Senhora da Oliveira de Guimarães.

Para a autora, as preocupações relacionadas à forma e ao estilo da redação dos milagres da santa denunciavam, além das questões relativas à produção de memória, uma preocupação em legitimar a uma nova mentalidade que ganhou força no período: a mentalidade urbana. Além disso, a circulação e a divulgação desse culto mariano asseguraram à região de Guimarães uma identidade e uma vitalidade propícias, que foram associadas à figura régia. Assim, criaram-se condições para o domínio do maravilhoso e para a formação da identidade nacional portuguesa.

Os problemas ligados à história de gênero foram abordados segundo uma história do imaginário político. Em sua dissertação de mestrado, Santos ${ }^{20}$ articulou temas, como, longa duração, história de gênero, culto mariano, centralização monárquica para estudar a construção do paradigma de rainha em Portugal. Na realidade, a autora demonstrou como o modelo de rainha desempenhou um importante papel na afirmação da identidade portuguesa.

Conforme já escrito, a sua investigação inscreveu-se na longa duração, pois se trabalhou de forma simultânea com dois recortes temporais: o reinado de D. Dinis, período marcado por um projeto de centralização, e o reinado de D. João III, época em que Portugal já se constituíra como um império colonial. Entre esses dois extremos temporais, encontra-se a elaboração da imagem de Isabel de Aragão, esposa de D. Dinis que, no século XVI, foi eleita defensora da nação portuguesa.

Para a composição da sua argumentação em relação ao papel ordenador do paradigma feminino para a sociedade portuguesa, em especial, para reconstituir a produçãocirculação-apropriação do paradigma "isabelino", cuja inspiração veio do culto mariano,

${ }^{16}$ Jacques Le Goff, L'imaginaire médiéval, essais. Paris : Gallimard, 1985.

${ }^{17}$ Idem, Histoire et mémoire. Paris: Gallimard, 1988.

${ }^{18}$ Idem. O maravilhoso e o quotidiano no Ocidente medieval. Lisboa: Edições 70, 1990.

${ }^{19}$ Beatriz de Vasconcellos Dias Miranda, Nossa Senhora da Oliveira e o Concelho de Guimarães. Niterói, 1993. Dissertação (Dissertação em História Social) - Instituto de Ciências Humanas e Filosofia, Universidade Federal Fluminense, Niterói, 1993.

${ }^{20}$ Georgina Silva Santos. A senhora do Paço: o papel da rainha na construção da identidade nacional portuguesa (1282-1557). Niterói, 1995. Dissertação (Mestrado em História Social) - Instituto de Ciências Humanas e Filosofia, Universidade Federal Fluminense, Niterói, 1995. 
Santos analisou conjuntamente diferentes recursos documentais. Em sua conclusão, demonstrou-se como o modelo teve uma grande eficácia simbólica, sobretudo, no que diz respeito à consolidação do papel da rainha como um exemplo de conduta feminina.

Fernão Lopes (1380-1460) e Gomes Eanes de Zurara (1420-1474) tiveram a sua produção cronística estudada para compreender o modo através do qual eles apresentaram as rainhas de Portugal. Assim, $\operatorname{Coser}^{21}$ investigou as representações criadas para a última rainha da dinastia de Borgonha - Leonor Teles (1350-1386), esposa do rei D. Fernando (1367-1383) - e para a primeira rainha da dinastia de Avis, Filipa de Lancaster (1360-1415), mulher do rei D. João I (1385-1433).

Ela constatou que a primeira rainha foi identificada com o reino de Castela enquanto que a segunda foi relacionada ao reino português. Para Coser, tal modelo associativo não foi aleatório. Ele recuperava a tradição cristã medieval que opunha Maria a Eva. Por esse motivo, a historiadora concluiu que o modo pelo qual as rainhas foram representadas também estava vinculado ao programa de legitimação da dinastia de Avis levado a cabo a partir de D. João I.

O tema do imaginário régio também foi estudado por Barros ${ }^{22}$ cuja pesquisa, além de produzir uma análise empírica do imaginário régio da centralização monárquica nos séculos XIII e XIV através do livro de linhagens e dos cancioneiros portugueses, apresentou um balanço historiográfico sobre o conceito de imaginário. $\mathrm{O}$ autor teve a preocupação de comprovar a relação entre o imaginário, espaço de luta simbólica, e os conflitos que aconteceram na corte régia portuguesa no período estudado. Colocou-se, portanto, contra as perspectivas historiográficas que defendem que o imaginário é um campo à parte, sem relação com os conflitos sociais.

Esse autor desenvolveu, provavelmente, devido à influência da Marc Bloch, uma análise comparativa com corte de Castela. Ele demonstrou como a metáfora, criada pelos

\footnotetext{
${ }^{21}$ Miriam Cabral Coser. Política e gênero: o modelo de rainha nas crônicas de Fernão Lopes e Zurara (Portugal - Séc. $X V$ ). Niterói, 2003. Tese (Doutorado em História Social) - Instituto de Ciências Humanas e Filosofia, Universidade Federal Fluminense, Niterói, 2003.

${ }^{22}$ José $\mathrm{D}^{\prime}$ Assunção Barros, As três imagens do rei: o imaginário régio nos livros de linhagens e nas cantigas trovadorescas portuguesas (séculos XIII e XIV). 2 Vols. Niterói, 1999. Tese (Doutorado em História Social) - Instituto de Ciências Humanas e Filosofia, Universidade Federal Fluminense, Niterói, 1999.
} 
juristas de Afonso X, de que "o rei é a cabeça, o coração e alma do reino", foi apropriada em Portugal e difundida durante o período por ele abordado.

No campo da história da saúde, $\operatorname{Bastos}^{23}$ articulou a concepção de "saúde pública" e com a ação centralizadora de Avis. No seu trabalho sobre as epidemias de peste que assolaram a sociedade portuguesa ao longo dos séculos XIV e XVI, o autor demonstrou como a dinastia de Avis produziu uma noção de doença, articulando-a ao processo de centralização. Assim, controlar as epidemias passou a ser uma função do nascente Estado. Nessa dissertação, apresentou-se como o processo de centralização de Avis associou a saúde do rei à saúde do reino.

A pesquisa de $\operatorname{Santos}^{24}$ investigou as Crônicas dos Reis de Fernão Lopes. Nessa pesquisa, adotaram-se os métodos de análise advindos da semiótica, especificamente, a análise de discurso de Courtés ${ }^{25}$. Com base nessa metodologia, a autora relacionou o texto do cronista à propaganda da dinastia de Avis. Ela mostrou como as crônicas escritas a pedido de D. Duarte representam uma elaboração idealizada da realidade conhecida pelo cronista, ou seja, o imaginário das relações entre Rei e o Povo de modo que o "real", da forma como ele foi representado pelo cronista, fosse representado segundo os interesses de Avis. Em sua conclusão, apontou que, embora essas categorias fossem antagônicas, eram, ao mesmo tempo, complementares. A relação de complementaridade era proveniente do fato de que, do ponto de vista discursivo, o Rei teria sido sustentado pelo Povo, o qual continuou a colaborar com o soberano no processo de centralização monárquica.

Ferreira $^{26}$ realizou um estudo comparativo das crônicas ibéricas produzidas nos séculos XIII e XV, visando a acompanhar o processo de construção do mito afonsino, o ato fundador da monarquia portuguesa por Deus e suas progressivas modificações. Relacionou-as com o processo de construção da identidade nacional portuguesa,

\footnotetext{
${ }^{23}$ Mário Jorge da Mota Bastos, $O$ "rei e a saúde do reino" a peste e o poder real em Portugal: séculos $X I V-X V I$. Niterói, 1995. Dissertação (Mestrado em História Social) - Instituto de Ciências Humanas e Filosofia, Universidade Federal Fluminense, Niterói, 1995.

${ }^{24}$ Ângela Maria Oliveira de Carvalho Santos, O rei e o povo nas crônicas de Fernão Lopes. Niterói, 1994. Dissertação (Mestrado em História Social) - Instituto de Ciências Humanas e Filosofia, Universidade Federal Fluminense, Niterói, 1994.

${ }^{25}$ Joseph Courtés, Analyse sémiotique du discours: de l'énoncé à l'énonciation. Paris : Hachette, 1991.

${ }^{26}$ Roberto G. Fabri Ferreira, O papel do maravilhoso na construção da identidade nacional portuguesa análise do mito afonsino (séc. XIII-XV). Niterói, 1997. Dissertação (Mestrado em História Social) Instituto de Ciências Humanas e Filosofia, Universidade Federal Fluminense, Niterói, 1997.
} 
indicando algumas pistas para se problematizar a própria particularidade da sacralidade da monarquia portuguesa.

Com base nas discussões relativas à percepção do tempo, Ferreira ${ }^{27}$, influenciado pelas pesquisas de Le Goff $^{28}$, discutiu, em sua tese, a mudança no uso e na percepção do tempo em Portugal. Ele acompanhou a utilização cada vez mais freqüente do sistema abstrato de medição, cujo surgimento contribuiu para a diminuição do uso das referências naturais e levou até ao aparecimento da medição mecânica do tempo. $\mathrm{O}$ autor comprovou que tal processo foi precoce em Portugal e ocorreu durante os primeiros anos da dinastia de Avis.

Por meio da análise das chancelarias, das crônicas e das obras religiosas elaboradas durante os reinados de D. João I e D. Duarte, Ferreira apresentou a forma como o tempo foi reorganizado e apropriado por esses reis. Além disso, o autor demonstrou como, subjacente ao processo de controle das atividades quotidianas, houve uma criação de uma utopia avisina que desloca a temporalidade para o futuro, promovendo assim uma idealização de Portugal.

Accorsi Júnior ${ }^{29}$ estudou parte da prosa avisina, mais especificamente, aquela produzida no período de D. Duarte e que estava sob seu patrocínio, buscando compreender o caráter civilizatório e legitimador desse discurso, tomando como parâmetro teórico Nobert Elias. Destaca-se sua proposta de compreender o jogo político da corte de Avis como um microcosmo da sociedade portuguesa à época, bem como sua perspicácia no sentido de apontar o lento processo de senhorização desenvolvido pelos filhos de D. João I e seus principais colaboradores, notadamente, o Condestável D. Nuno Álvares.

\footnotetext{
${ }^{27}$ Idem O tempo novo e a origem dos novos tempos: a construção do tempo e da temporalidade nos primórdios da dinastia de Avis (1370 a 1440), Niterói, 2003. 2 Vols. Tese (Doutorado em História Social) - Instituto de Ciências Humanas e Filosofia, Universidade Federal Fluminense, Niterói, 1999.

${ }^{28}$ Jacques Le Goff. Pour un autre Moyen Age. Temps, travail et culture en Occident : 18 essais. Paris : Gallimard, 1977.

${ }^{29}$ Paulo Accorsi Júnior. Do Azambujerio Bravo à Mansa Oliveira: a prosa civilizadora da Corte do rei D. Duarte (1412-1438). Niterói, 1997. Dissertação (Mestrado em História Social) - Instituto de Ciências Humanas e Filosofia, Universidade Federal Fluminense, Niterói, 1997.
} 
Por meio dos debates sobre as singularidades do indivíduo, Berriel ${ }^{30}$ problematizou o discurso moralizador do clero português no final do século XIV e no início do XV. Tomando como parâmetro a noção de indivíduo, considerado como uma categoria da cultura, o autor expôs como a literatura moralizante o reconhecia e propunha a sua salvação. Segundo essa perspectiva, foi possível identificar os vetores que constituíram a individualidade ao mesmo tempo em que se explica a sua inserção no coletivo através do discurso da salvação dos fiéis. Ao investigar o Orto do Esposo, cuja autoria é desconhecida, defendeu-se que seria possível encontrar certo grau de individualidade, embora sejam evidentes os mecanismos de controle da subjetividade.

Em sua investigação de doutorado ${ }^{31}$, voltou-se para a produção simbólica dos franciscanos portugueses durante grande parte do século XV. Tomou como objeto a estruturação da representação social de Cristão, presente no discurso franciscano, para comprovar que ela se associava à noção de Súdito. Assim, segundo o autor, por meio dessa aproximação, os franciscanos delinearam um equilíbrio entre os poderes temporal e espiritual.

Destaca-se o fato de que o autor não tenha fixado o seu estudo apenas no campo das representações, uma vez que ele demonstrou que a construção ideológica estava de acordo com o universo das práticas sociais, nas quais os reis de Avis e os frades menores apoiavam-se mutuamente. Do ponto de vista do material analisado, as fontes foram as obras Horologium Fidei, de mestre André do Prado, A História Seráfica da Ordem dos Frades Menores de S. Francisco, escrita pelos freis Manoel da Esperança e Femando de Soledade, as Crónicas da Ordem dos Frades Menores, de frei Marcos de Lisboa. No que diz respeito ao discurso de Avis, estudaram-se a Crónica de D. João I, de Fernão Lopes, a Crónica da Tomada de Ceuta, de Zurara, e o Livro da Vertuosa Benfeytoria, obra do infante D. Pedro e do frei dominicano João Verba.

\footnotetext{
${ }^{30}$ BERRIEL, Marcelo Santiago. Individuo e comunidade cristã na prosa moralística portuguesa (séculos $X I V$ e XV). Niterói, 2002. Dissertação (Mestrado em História Social) - Instituto de Ciências Humanas e Filosofia, Universidade Federal Fluminense, Niterói, 2002.

${ }^{31}$ Idem, Cristão e súdito: representação social franciscana e poder régio em Portugal (1383-1450). Niterói, 2007. Tese (Doutorado em História Social) - Instituto de Ciências Humanas e Filosofia, Universidade Federal Fluminense, Niterói, 2007.
} 
Queirós $^{32}$ pesquisou a imagem produzida pelo cronista-mor de D. Afonso V, Eanes de Zurara, do infante D. Henrique, tomando como paradigma a figura real. Em suas conclusões, percebe-se que o discurso cronístico foi um suporte para divulgação de modelos de príncipe, de rei e de súdito. Tal estratégia contribui de forma inquestionável para a afirmação de identidade nacional portuguesa.

A prosa de Fernão Lopes foi também investigada por Dantas ${ }^{33}$, cujo estudo analisou a Crônica de D. Fernando escrita por volta de 1436. Para a autora, o cronista régio, fortemente vinculado com a causa de Avis, teria produzido um paradigma que, ao mesmo tempo que enunciava um modelo de realeza ideal, construía sua contrapartida na personagem de D. Fernando, último rei da dinastia de Borgonha.

Fernandes $^{34}$ discutiu a implantação do poder senhorial da Ordem do Templo nas vilas de Egas, Soure, Redinha, Pombal e Louriça no período de 1129 a 1231 . O autor partiu do pressuposto de que a força conseguida por essa ordem na região veio de sua capacidade de se adaptar ao crescimento urbano e à difusão de uma economia monetária, que estava associada à administração da justiça senhorial na região.

Em sua tese de doutorado ${ }^{35}$, realizada em outra universidade - Universidade Federal do Rio de Janeiro $(\mathrm{UFRJ})^{36}$ - ele continuou a questionar-se sobre ao papel das ordens militares em Portugal. No entanto, embora tenha continuado com o mesmo orientador ${ }^{37}$,

\footnotetext{
32 Sílvio Galvão de Queirós, Pera Espelho de Todollos Uiuos - A imagem do Infante D. Henrique na Crônica da Tomada de Ceuta. Niterói, 1997. Dissertação (Mestrado em História Social) - Instituto de Ciências Humanas e Filosofia, Universidade Federal Fluminense, Niterói, 1997.

${ }^{33}$ Cláudia Côrrea Dantas, Dom Fernando, um príncipe imperfeito: análise de um contra-modelo de rei. Niterói, 1999. Dissertação (Mestrado em História Social) - Instituto de Ciências Humanas e Filosofia, Universidade Federal Fluminense, Niterói. 1999.

${ }^{34}$ Fabiano Fernandes. Terras, poderes e conflitos: O poder senhorial da Ordem do Templo e as vilas de Egas, Soure, Redinha, Pombal e Louriçal 1129-1231. Niterói, 1999. Dissertação (Mestrado em História Social) - Instituto de Ciências Humanas e Filosofia, Universidade Federal Fluminense, Niterói. 1999.

${ }^{35}$ Idem, $O$ "reino de Deus e a espada do rei": A formação do poder eclesiástico da Ordem de Cristo nas comendas de Ega, Soure, Redinha e Pombal, na primeira metade do século XIV. Rio de Janeiro, 2005. Tese (Doutorado em História) - Instituto de Ciências Sociais, Universidade Federal do Rio de Janeiro, Rio de Janeiro. 2005.

${ }^{36}$ Infelizmente, por problemas técnicos não foi possível acessar o catálogo on-line desta universidade. Entretanto, declare-se que, atualmente, a instituição tem uma significativa produção sobre idade média e disponibiliza em PDF algumas teses e dissertações defendidas junto ao programa de pós-graduação. Para maiores informações Cf. Disponível em: <www.minerva.ufrj.br>. Acesso em 28 de janeiro 2008.

37 Professor Doutor Francisco José Gomes Silva. Esse pesquisador destaca-se pelos seus questionamentos em torno da história da Igreja medieval e do período colonial. Atualmente, desenvolve suas pesquisas junto à Universidade Federal do Rio de Janeiro onde tem orientado dissertações e teses sobre as temáticas ligadas à história eclesiástica. Cf. Francisco José Silva Gomes. A igreja e o poder: representações e discursos. in: Maria Eurydice de Barros Ribeiro(org.). A idade média. Brasília: UNB,
} 
enveredou-se um pouco mais nos caminhos das relações entre o Estado e Igreja. Nessa pesquisa, após fazer uma minuciosa análise do contexto da dissolução da Ordem do Templo, evidenciou as singularidades desse processo em Portugal que teve como resultado a criação da Ordem de Cristo na primeira metade do século XIV. Ele partiu da hipótese de que a grande proximidade criada entre a Ordem do Templo e o Estado português devido à reconquista é um dos elementos para o entendimento da criação da Ordem de Cristo em Portugal ${ }^{38}$.

A pesquisa sua inscreve-se também nas problematizações feitas por Alves ${ }^{39}$, que atualmente é vinculada ao programa de pesquisa em história medieval da Universidade Federal do Rio de Janeiro onde, do mesmo modo que Gomes, vem desenvolvendo pesquisas em idade média. Ela mapeou os conflitos que ocorreram na região de Pombal, Ega e Redinha entre 1385 e 1481. A autora analisou os choques de interesses entre os poderes senhoriais (leigos e eclesiásticos), os concelhos e os agentes régios. A historiadora indicou como o poder real, através da ação dos seus agentes, conseguiu se impor, quer do ponto de vista simbólico, quer do ponto de vista da administração da justiça.

Ao analisar as querelas na região, mostrou como ocorreram transformações expressivas, cujo resultado foi a imposição do poder régio como o mais importante da região. Para corroborar a sua argumentação, a autora, inicialmente, fez uma caracterização espacial da região, estudou o processo de ocupação através da análise do processo de povoamento e, por último, apresentou as causas dos conflitos na região e os mecanismos utilizados pelo poder régio para se afirmar. Entre as diversas fontes

1999, pp. 33-59.; Francisco José Silva Gomes, A cristandade medieval entre o mito e a utopia. In: Topoi. Revista de história do programa de pós-graduação em história social da UFRJ. Rio de Janeiro: Editora \& Letras, Vol. 5, pp. 221-231, set. 2002.

${ }^{38}$ Do ponto de vista do debate historiográfico, esse autor discute autores, como, por exemplo: Leila Rodrigues da Silva, Algumas considerações acerca do poder episcopal nos centros urbanos hispânicos séculos V ao VII. História Questões \& Debates - Instituições e Poder no Medievo. Curitiba: Editora da UFPR, Ano 19, no 37, pp. 67-84, julho a dezembro de 2002. A pesquisadora é também vinculada ao programa de pesquisa em história da Universidade Federal do Rio de Janeiro, onde desenvolve investigações em relação à idade média, sobretudo, a alta idade média ibérica.; Margarida Garcez Ventura, Igreja e poder no séc. XV. Dinastia de Avis e liberdades eclesiásticas (1383-1450). Lisboa: Edições Colibri, 1997. Com Ventura, Fernandes debateu a questão das liberdades eclesiásticas.; Maria Helena da Cruz Coelho \& Armando Luís de Carvalho Homem. Nova história de Portugal. Portugal em definição de fronteiras. Vol. III. Lisboa: Presença, 1997.

${ }^{39}$ Gracilda Alves, Poder e sociedade na região de Pombal, Soure, Ega e Rendinha (1385-1481). Niterói, 2001. Tese (Doutorado em História Social) - Instituto de Ciências Humanas e Filosofia, Universidade Federal Fluminense, Niterói, 2001. 
analisadas, destacam-se as cartas de perdão dadas pelos monarcas do período. Alves expôs como elas foram importantes para o processo de centralização régia.

A concepção de territorialidade portuguesa no final da idade média e suas relações com o poder régio e a cultura escrita foi o objeto da pesquisa desenvolvida por Mello ${ }^{40}$ que reconstituiu os mecanismos de circulação e apropriação do livro Vita Chrisit de Ludolfo da Saxônia. Nessa reconstituição, chegou-se às leituras que foram feitas por D. Duarte e pelos monges do mosteiro de Santa Maria de Alcobaça. A autora abordou como o rei teve acesso, por meio da instituição eclesiástica, a um conjunto de obras cujos conteúdos teriam contribuído em sua formação. Para Mello, esse monarca não só freqüentou o mosteiro como o auxiliou na formação do seu acervo. Entretanto, um dado trazido pela pesquisadora é de que D. Duarte possuía uma herança intelectual que extrapolava os limites desse scriptorium, uma vez que era conhecedor de muitas obras que estavam ausentes das suas estantes. Em sua conclusão, corroborou a sua hipótese de que o conhecimento "bibliográfico" do rei teria contribuído para a elaboração de sua concepção sobre a territorialidade lusa.

Um dos temas recorrentes na produção do Scriptorium - Laboratório de Estudos Medievais e Ibéricos diz respeito aos mecanismos da produção da memória por parte da realeza. Dentro dessa perspectiva, encontra-se a pesquisa de $\operatorname{Lacê}^{41}$, cujo estudo analisou as imagens produzidas sobre o rei D. Afonso Henriques nas memórias hagiográficas de Santa Cruz de Coimbra em meados do século XII. A autora corroborou que essas representações foram produzidas com grande grau de intencionalidade de forma a sacralizar a personagem régia. Nesse modelo, o rei foi, freqüentemente, associado às noções de zeloso da fé, guerreiro e santo pelos cônegos agostinianos. Tal representação teria contribuído para a criação do paradigma de rei perfeito.

\footnotetext{
${ }^{40}$ Priscilla Leal Mello. Espada de rei, arma de senhorio: o livro na formação da territorialidade portuguesa (séculos XV-XVI). Niterói, 1999. Dissertação (Mestrado em História Social) - Instituto de Ciências Humanas e Filosofia, Universidade Federal Fluminense, Niterói. 1999.

${ }^{41}$ LACÊ, Andréia Mello Lacê, A produção da imagem do Rei Afonso Henriques nas memórias hagiográficas de Santa Cruz de Coimbra - século XII. Niterói, 2002. Dissertação (Mestrado em História Social) - Instituto de Ciências Humanas e Filosofia, Universidade Federal Fluminense, Niterói. 2002.
} 
No que diz respeito à tradição ibérica de sacralização da guerra, a investigação de $\operatorname{Costa}^{42}$ sobre a permanência da mentalidade de cruzada no imaginário cavaleiresco ibérico durante a reconquista portuguesa, apresentou um debate historiográfico sobre a questão da mentalidade de cruzada em Portugal. A sua análise foi assentada em fontes narrativas, cujas histórias reportavam aos episódios da conquista de Lisboa de 1147 e da batalha de Salado de 1340. Ele defendeu que teria ocorrido em Portugal uma releitura dessa mentalidade baseada Libro del Orden de Caballería, de Ramón Llull. Tanto o lulismo como o paradigma cavaleiresco devem ser considerados como indícios da permanência de uma mentalidade de cruzada em Portugal. Através do estudo do significado do símbolo Santo Lenho do Marmelar, um objeto cristológico presente tanto na conquista de Lisboa como na batalha do Salado, o autor reconstitui a relação entre o ideal de cruzado e as manifestações maravilhosas em torno da relíquia.

Nesse estudo, nota-se uma influência da investigação de Matoso sobre a nobreza portuguesa. Costa evidenciou como no Livro de Linhagens surgem idealizações sobre a Ordem do Hospital de São João de Jerusalém e a família dos Pereiras a qual, personificada na figura do prior do Hospital em Portugal, D. Álvaro Gonçalves Pereira, foi relatada como uma linhagem cruzadística portuguesa.

Lopes $\mathrm{Neto}^{43}$ empreendeu um estudo sobre a formulação da imagem de D. Afonso V, um rei que, por se adequar às prerrogativas medievais da utilização da justiça, teve a sua imagem associada à de rei justo e piedoso. Baseando-se na análise, principalmente, das Ordenações Afonsinas, a autora comprovou sua hipótese de que a justiça, como representação e como prática social, é um dos elementos fundamentais para a instauração da ordem político-social no interior do reino. Um dos eixos desse estudo estabeleceu um debate em torno do reinado de $\mathrm{D}$. Afonso $\mathrm{V}$, freqüentemente associado a um período de instabilidade no reino e ou a um retrocesso do processo de centralização.

\footnotetext{
${ }^{42}$ Ricardo Luiz Silveira da Costa, A cruz do santo lenho do Marmelar: a permanência da mentalidade de cruzada no imaginário cavaleiresco ibérico durante a Reconquista portuguesa (séculos XII-XIV). Niterói, 1997. Dissertação (Mestrado em História Social) - Instituto de Ciências Humanas e Filosofia, Universidade Federal Fluminense, Niterói, 1997.

${ }^{43}$ Emmanuelle de Souza Lopes Neto. Um rei justo para uma sociedade perfeita. Niterói, 2002. Dissertação (Mestrado em História Social) - Instituto de Ciências Humanas e Filosofia, Universidade Federal Fluminense, Niterói, 2002.
} 
As crônicas dos reis Sancho II e Afonso III de Portugal foram examinadas ${ }^{44}$ para evidenciar como teria havido uma apropriação lusa da imagem do rei Artur contida na Historia Regum Britanniae de Geoffroy de Monmouth. A apropriação portuguesa teve por base a representação guerreira do rei inglês para realizar a sua releitura. No caso do país Atlântico, como a guerra estava sempre presente foi possível notar uma transposição do modelo guerreiro arturiano para a imagem de Afonso III, porém isso não ocorreu em relação ao seu antecessor. A historiadora comprova como a imagem de Sancho II foi construída de modo a impregná-lo de elementos negativos, justificando assim a sua deposição por Afonso III.

O imaginário político português em seu viés messiânico e escatológico foi o foco de Zierer $^{45}$ ao estudar a prosa de Fernão Lopes. Nessa tese, estabeleceu-se um diálogo com os estudos de Rabelo ${ }^{46}$ sobre as concepções de poder expressas em Fernão Lopes. Dentro dessa perspectiva, demonstrou-se como existe uma relação entre o programa de consolidação da dinastia com as representações de cunho escatológico e messiânico. Para a autora, a representação do reino é edenizada e aproxima-se dos elementos imaginários contidos principalmente na Visão de Túndalo, O Conto do Amaro, A Demanda do Santo Graal e no Libro del Infante Don Pedro de Portugal. Ela concluiu ainda que tais associações não eram aleatórias e faziam parte do programa ideológico difundido pelo Paço de Avis.

Em sua pesquisa Amaral ${ }^{47}$ conseguiu comprovar a existência de uma demanda ideológica por santidade na casa de Avis durante o processo de conquista do Norte da África. Conseguiu revelar, através do estudo das crônicas de Zurara e do Frei João Álvares, como foram difundidos exempla cujos conteúdos "santificavam" os membros de Avis envolvidos com a expansão marítima. Na realidade, o autor apresentou a existência de uma unidade discursiva para tratar do tema da expansão. Além disso,

\footnotetext{
${ }^{44}$ Adriana Maria de Souza Zierer. O modelo Arturiano em Portugal: a imagem do Rei-Guerreiro na construção cronista de Sancho II e Afonso III. Niterói, 1999. Dissertação (Mestrado em História Social) Instituto de Ciências Humanas e Filosofia, Universidade Federal Fluminense, Niterói, 1999.

${ }^{45}$ Idem, Paraíso, escatologia e messianismo em Portugal à época de D. João I. Niterói, 2004. Tese (Doutorado em História Social) - Instituto de Ciências Humanas e Filosofia, Universidade Federal Fluminense, Niterói. 2004.

${ }^{46}$ Cf. Luís de Sousa Rabelo. A concepção de poder em Fernão Lopes. Lisboa: Livros Horizonte, 1983.

${ }^{47}$ Clinio de Oliveira Amaral, A construção de um Infante Santo em Portugal: (1438-1481). Niterói, 2004. Dissertação (Mestrado em História Social) - Instituto de Ciências Humanas e Filosofia, Universidade Federal Fluminense, Niterói, 2004.
} 
corroborou a hipótese de que essa unidade discursiva, construída em torno das idéias de missão e predestinação da nação portuguesa, foram utilizadas para reler a derrota de Tânger, em 1437, ao mesmo tempo que transformaram o infante D. Fernando em mártir nacional. Do ponto de vista historiográfico, foi retomado o debate sobre as categorias do sagrado cristão ${ }^{48}$ e sobre o uso do conceito de propaganda régia para o final da idade média ibérica ${ }^{49}$.

A pesquisa de Mello $^{50}$ concentrou-se na análise da relação entre as cerimônias e os rituais do poder régio e o processo de centralização monárquica. Em seu trabalho, há um debate com as pesquisas de Mattoso $^{51}$, especificamente, no que diz respeito às transformações sofridas no papel do rei, de Soria ${ }^{52}$, no que tange à função da cerimônia, e de Gomes ${ }^{53}$ sobre a questão do ritual. Mello ainda retoma as discussões de $\mathrm{Amaral}^{54} \mathrm{e}$ de Lopes $\mathrm{Neto}^{55}$ sobre a relativização da idéia de que o governo de $\mathrm{D}$. Afonso $\mathrm{V}^{56}$ teria representado um retrocesso no processo de centralização desenvolvido desde D. João I.

Ao estudar as transformações no ritual de homenagem entre 1438 e 1495, ela reconstituiu a "evolução" do seu significado político. Portanto, apresentaram-se as modificações da representação do rei como primus inter paris a de adversário, de

\footnotetext{
${ }^{48}$ Cf. Jacques Le Goff. Saint Louis. Paris: Gallimard, 1996.; Idem. Aspects religieux et sacrés de la monarchie française $d u X^{e}$ au XIII siècle. in : BOUREAU, Alain Boureau et Claudio-Sergio Ingerflom (orgs.). La royauté sacrée dans le monde chrétien. (Colloque de Royaumont, mars 1989). Paris: École des Hautes Études en Sciences Sociales. 1992. pp. 19-28.

${ }^{49}$ Cf. José Manuel Nieto Soria, Fundamentos ideológicos... op. cit.; Idibem. Ceremonias de ... op. cit.

${ }^{50}$ Ieda Avênia de Mello, Rituais e cerimônias régias da Dinastia de Avis: pacto e conflito na entronização de D.João II (Portugal-1438-1495). Niterói, 2007. Dissertação (Mestrado em História Social) - Instituto de Ciências Humanas e Filosofia, Universidade Federal Fluminense, Niterói, 2007.

${ }_{51}^{51}$ José Mattoso, A nobreza medieval portuguesa - a família e o poder. Lisboa: Estampa, 1980.

${ }^{52}$ José Manuel Nieto Soria, Ceremonias de... op. cit.

${ }^{53}$ Rita Costa Gomes, A corte dos reis portugueses no final da idade média. Lisboa: Difel, 1995.

${ }^{54}$ Clinio de Oliveira Amaral, A construção... p. cit.

${ }_{55}^{55}$ Emmanuelle de Souza Lopes Neto, Um rei... op. cit.

${ }^{56}$ Para se ter uma noção das diversas posições sobre esse reinado na historiografia portuguesa. Cf. Luís Miguel Duarte, Justiça e criminalidade em Portugal medievo (1459-1481). Lisboa: FCG/FCT, 1999. Segundo ele, não se encontram páginas nem muito empolgantes nem elogiosas em relação a tal rei. Seu estudo sobre a formação do aparelho judicial português não conseguiu esclarecer satisfatoriamente o papel desempenhado por D. Afonso V na construção da imagem do rei como misericordioso e legislador.; Joaquim Veríssimo Serrão, "Afonso V In: Dicionário de história de Portugal. Vol. I, Lisboa: Figueirinhas. pp. 42-44. Para ele, D. Afonso V foi responsável por atender aos interesses das grandes casas senhoriais em detrimento do patrimônio da casa real.; Marcello Caetano, História do direito português: fontes do direito público (1140-1495). Lisboa/São Paulo: Verbo, $2^{\mathrm{a}}$ ed.,1985. Segue a linha argumentativa de Serrão, porém apresenta uma crítica voraz a D. Afonso V, fazendo até mesmo críticas de cunho moral.; José Hermano Saraiva, História concisa de Portugal. [s. 1.] Publicações EuropaAmérica, $21^{a}$ ed., 2001. Em sua análise sobre D. Afonso V, estabelece uma relação entre uma identificação da política nacional com os interesses da alta nobreza.
} 
adversário à árbitro e, por fim, da condição de árbitro a de sustentáculo fundamental tal como Mattoso definiu ${ }^{57}$.

Outra linha pesquisa desenvolvida pelo Scriptorium diz respeito à grande temática da cultura e estética medieval. Temas, como, por exemplo, a iconografia medieval, a literatura medieval, a música medieval e o teatro constituem-se como objetos privilegiados.

No que diz respeito às análises iconográficas existem trabalhos que abordam o material de livro de horas presentes na Biblioteca Nacional do Rio de Janeiro. Há algum tempo Fróes $^{58}$ vem estudando as representações do reino de Portugal entre 1378 a 1528 através das iluminuras dos livros de Horas Portugueses que estão na Biblioteca Nacional do Rio de Janeiro. Do ponto de vista das influências historiográficas, nota-se uma referência aos trabalhos sobre o estudo da iconografia medieval iniciados por Schmitt ${ }^{59}$.

Dentro da perspectiva da iconografia medieval, a pesquisa de Vieira ${ }^{60}$ analisou, sem deixar de lado as questões técnicas da numismática, as representações do rei D. Fernando I revelada pela Coleção de Moedas do Museu Histórico Nacional. Ela propôs uma análise das funções simbólicas das imagens difundidas pelas emissões do período. Além disso, fez uma revisão da história monetária daquela época.

O reinado de D. João II foi estudado, do ponto de vista da articulação entre ação centralizadora e o imaginário régio, por Silva ${ }^{61}$. Ela analisou as crônicas escritas nos séculos XV e XVI sobre esse rei, bem como a representação iconográfica da empresa real, cujo tema é o pelicano. Assim, debateram-se questões de memória e de identidade,

\footnotetext{
${ }^{57}$ José Mattoso,. A nobreza... op. cit., p. 21.

${ }^{58}$ Vânia L Fróes, "Imagem e identidade: estudo das representações iconográficas nos Livros de Horas Portugueses da Biblioteca Nacional do Rio de Janeiro" In: Actas do IV Colóquio de Estudos Históricos do Brasil-Portugal. Porto: Editora Portucalense, 1999, pp. 36-46.

59 Como esse autor tem inúmeros estudos sobre as imagens medievais, citam-se à guisa de marcos cronológicos a sua pesquisa inicial e o um outro livro mais recente dedicado ao estudo das imagens; JeanClaude Schmitt, La raison des gestes dans l'Occident médiéval. Paris : Gallimard, 1990.; Idem, Le corps des images : essais sur la culture visuelle au Moyen Age. Paris : Gallimard, 2002.

${ }^{60}$ Rejane Maria Lobo Vieira. A imagem do Rei e do reino de Portugal através das moedas de D. Fernando I (1367-1383). Niterói, 1994. Dissertação (Mestrado em História Social) - Instituto de Ciências Humanas e Filosofia, Universidade Federal Fluminense, Niterói, 1994.

61 Priscila Aquino Silva, Entre príncipe perfeito e rei pelicano: os caminhos da memória e da propaganda política através do estudo da imagem de D. João II (século XV). Niterói, 2007. Dissertação (Mestrado em História Social) - Instituto de Ciências Humanas e Filosofia, Universidade Federal Fluminense, Niterói, 2007.
} 
segundo os pressupostos da Nova História. Estabeleceu-se um diálogo com o trabalho de $\operatorname{Costa}^{62}$ devido à sua análise da simbologia do poder português. Segundo a autora, a associação do rei à imagem do pelicano tinha como propósito legitimar o seu processo de centralização. Ela recuperou o sentido desse animal para o imaginário cristão. No imaginário medieval, o pelicano representava o pai que se esforça para proteger e sustentar os filhos. O animal também resgata a idéia do assistencialismo, que foi bastante incentivado por D. João II.

No que diz respeito à literatura medieval, sublinha-se as pesquisas de Gonçalves ${ }^{63}$ que, através dos romances de cavalaria do final do século XII, problematizou as transformações do imaginário Europeu ao estudar a forma como a narrativa de Tristão e Isolda, considerando as suas diversas versões, representou os dualismos no conflito entre paixão e casamento ${ }^{64}$. A oposição escolhida como objeto de estudo foi a das representações e experiências da corte e da floresta. Segundo o autor, o conflito contido nesses pares opostos foi solucionado pela proposição de uma viagem, no sentido cavaleiresco do termo. Ela teria como resultado a transformação daquele que a empreendeu.

Em sua tese de doutorado, Gonçalves ${ }^{65}$ retoma uma discussão que foi protagonizada por Gurevic $^{66}$ em relação dos processos de formação da consciência individual. Gonçalves, através das narrativas de Erec e Enide, Cligès, Yvain, o Cavaleiro do Leão e Lancelot, o Cavaleiro da Charrete, investigou os modelos de realização da pessoa difundidos pelo ideal cortês, seus conflitos e suas interações. A temática do amor foi privilegiada para demonstrar a irrupção, no amante, de sentimento de separação. Tal sentimento é

\footnotetext{
${ }^{62}$ Rita Costa Gomes, A corte... op. cit.; José Manuel Nieto Soria. Fundamentos ideológicos... op. cit.; Idem, Ceremonias de ... op. cit.; Georges Balandier. Le pouvoir sur scènes. Paris: Balland, 1980.

${ }^{63}$ Sínval Carlos Mello Gonçalves, Tristão e Isolda: a viagem da paixão: o imaginário do amor no século XII. 1997. Dissertação (Mestrado em História Social) - Instituto de Ciências Humanas e Filosofia, Universidade Federal Fluminense, Niterói, 1997.

${ }^{64}$ Esse autor discute temas como os trazidos por: Paul Zumthor, Essais de poétique médiévale. Paris: Seuil, 1972.; Idem, Langue, texte, énigme. Paris: Seuil, 1975.; Idem, La lettre et la voix: de la littérature médiévale. Paris: Seuil, 1987.

${ }^{65}$ Idem, Na medida do impossível: O cavaleiro além da cavalaria nos romances de Chrétien de Troyes (1165-1191). Niterói, 2004. Tese (Doutorado em História Social) - Instituto de Ciências Humanas e Filosofia, Universidade Federal Fluminense, Niterói, 2004.

${ }^{66}$ Aaron J. Gurevitch, "Au Moyen Age: conscience individuelle et image de l'au-delà", Annales Économies Sociétés Civilisations. Paris : E.H.E.S.S, Année 37e $\mathrm{n}^{\mathrm{0}}$ 2, pp. 255-275, mai-avril, 1970. Atualmente, essa temática foi alvo de novos questionamentos na Ecoles des Hautes Etudes en Sciences Sociales. Cf. Jean-Claude Schmitt, "L'invention de l'anniversaire". Annales Économies Sociétés Civilisations. Paris : E.H.E.S.S, Année 62 ${ }^{\mathrm{e}}, \mathrm{n}^{\circ}$ 4, pp. 793-835, juillet-août, 2007.
} 
superado por meio de uma aventura, que está relacionada ao reino do herói. Nas narrativas, estão presentes duas formas de amor que são opostas. Em uma delas, o amor se realiza no casamento enquanto que na outra, ele não se concretiza. Desta forma, para o historiador, as duas formas de narrativas geram dois modos de realização da pessoa. No primeiro, a imagem de perfeição através da realeza e do casamento, pode ser representada. No segundo, ela é percebida como um negativo do herói.

Sobre o teatro medieval, Pereira ${ }^{67}$ revisitou os estudos de Balandier ${ }^{68}$, Nieto Soria $^{69}$ e Fróes $^{70}$, para analisar a imagem do pastor nos autos de Juan de Encina e Lope de Rueda. Associou-se a tradição cristã e grego-romana às apropriações feitas pelo poder régio dessas tradições. A autora colocou que tais encenações antecediam as aparições públicas do rei. Assim, sustentou-se que a forma como o pastor foi representado serviu como um elemento da propaganda política da dinastia. Dentro dessa perspectiva, a investigação sobre o teatro ajuda a revelar como o poder manipula, relê e se apropria do imaginário social.

Dentro do mesmo campo de reflexão em relação ao poder régio, mas utilizando outro tipo de fontes está a pesquisa de Mendes $^{71}$, que tomou a música como principal fonte para a compreensão da dinastia de Avis. O poder régio fez grande uso de diferentes formas de espetáculo para veicular a imagem de riqueza e poder tanto para a cristandade quanto para os seus súditos. Ao investigar o espetáculo, propôs-se uma associação entre o estudo da música e do teatro, pois se defendeu que existe, no teatro de Gil Vicente, um conjunto discursivo, denominado pela autora com base em Fróes ${ }^{72}$ de discurso do paço, no qual, as encenações teatrais, as danças, as músicas representam as glórias dos descobrimentos. Mendes demonstrou como a música desempenhou um papel importantíssimo no teatro de Gil Vicente. Além das obras desse autor, foram estudadas

\footnotetext{
${ }^{67}$ Raquel Alvitos Pereira, Pastores de Deus, pastores del Reino de Espña: um estudo da produção da imagem dos rústicos no teatro do Baixo Medievo (sécs. XV-XVI). Niterói, 2005. Dissertação (Mestrado em História Social) - Instituto de Ciências Humanas e Filosofia, Universidade Federal Fluminense, Niterói, 2005.

${ }^{68}$ Georges Balandier,. Le pouvoir... op. cit.

${ }^{69}$ José Manuel Nieto Soria, Fundamentos ideológicos... op. cit.; Idem. Ceremonias de... op. cit.

${ }^{70}$ Vânia L. Fróes, Espaço e...op. cit.; Idem, Teatro como... op. cit.

${ }^{71}$ Lenora Pinto Mendes, $A$ música no teatro de Gil Vicente: a função do espetáculo no projeto político da Dinastia de Avis (?1465-1536). Niterói, 2004. Tese (Doutorado em História Social) - Instituto de Ciências Humanas e Filosofia, Universidade Federal Fluminense, Niterói, 2005.

${ }^{72}$ Cf. Nota $n^{\circ} .11$.
} 
as músicas utilizadas em sua dramaturgia que são provenientes de cancioneiros portugueses e espanhóis.

Selles $^{73}$, cujo objeto privilegiado também foi a música medieval, questionou o papel desempenhado por ela na propaganda política. Segundo o autor, a música possuiu um caráter aglutinador e foi demasiadamente utilizada na Europa da baixa idade média como forma de exibição de poder. No caso de sua pesquisa, que se insere na longa duração, pois estudou todo o período da dinastia de Avis, ele demonstrou como as idéias de glória, de magnificência, de riqueza, de fama e de cultura foram associadas ao rei e ao reino no período em questão. Selles investigou uma série de cerimônias régias, como, por exemplo, entradas, aclamações, casamentos, funerais etc. Um outro foco da pesquisa foi o estudo da inserção direta do poder real na organização musical portuguesa através da concessão de privilégios e proteção de artistas nas Cortes e Capelas. Além dos tratados musicais do período, analisaram-se as crônicas, os cancioneiros poéticos e musicais e os manuais de comportamento de cortesão.

Temas como as relações de produção nas sociedades do medievo através do questionamento das diversas formas apropriação e de organização do trabalho naquelas sociedades fizeram parte das pesquisas de $\mathrm{Garcia}^{74}$, que utilizou os manuais de confissão para apreender as concepções de trabalho. Assim, apresentou as hierarquias sociais segundo os manuais ao mesmo tempo que discutiu a lugar do indivíduo ou dos grupos no interior das atividades e funções ligadas aos "ofícios" e inscritos na sociedade medieval portuguesa dos séculos XIV e XV.

A autora coloca que nos manuais, cujo conteúdo representa um dos discursos da igreja, e nas Constituições Sinodais alguns ofícios ligavam-se aos pecados. No entanto, ela contrapôs a visão eclesiástica à visão sobre essa temática contida nas Ordenações Afonsinas para se demonstrar os pontos de convergência e de desacordo sobre os ofícios tidos como "lícitos" e os "ilícitos".

\footnotetext{
${ }^{73}$ Márcio Paes Selles. Entre a corte e a capela: o espetáculo como legitimação de poder e propaganda na Dinastia de Avis (1385-1574). Niterói, 2005. Tese (Doutorado em História Social) - Instituto de Ciências Humanas e Filosofia, Universidade Federal Fluminense, Niterói, 2005.

${ }^{74}$ Rosa Maria Duarte Soares Garcia, Oração e trabalho: as atitudes mentais em relação ao pecado e aos ofícios na sociedade medieval portuguesa dos séculos XIV e XV. Niterói, 1993. Dissertação (Mestrado em História Social) - Instituto de Ciências Humanas e Filosofia, Universidade Federal Fluminense, Niterói. 1993.
} 
Embora os estudos sobre Portugal sejam significativos do ponto de vista numérico, destaca-se o trabalho de Oliveira ${ }^{75}$ cujo estudo abordou a personagem de Rodrigo Diaz de Vivar, acunhado Cid. Tomou-o como referência paradigmática daqueles que transformaram a guerra em meio de vida de indivíduos desenraizados. Enfatizou-se o episódio da conquista de Valência em 1238.

As pesquisas desenvolvidas por Mônica Farias Fernández em sua dissertação de mestrado e tese de doutorado tem como núcleo o estudo da realeza castelhana. Em seu mestrado $^{76}$, estudou, para Castela do século XIII, a apropriação, produção e circulação dos modelos de representação da Virgem Maria. Ela os articulou ao reinado de D. Afonso X, especificamente, ao processo de centralização em curso. Quanto ao seu doutorado $^{77}$, a autora procura, numa perspectiva político-cultural, discutir a imagem sacralizada do rei sábio associado às figuras salomônicas no processo de centralização do poder real em Castela à época de D. Afonso X.

Ainda em relação ao tema do poder régio/identidade, mas fora dos debates sobre Península Ibérica, a tese de doutorado de Freitas $^{78}$ problematizou o modelo de identitário contido nos Decem Libri Historiarum de Gregório de Tours. Destacou-se a articulação das noções de santidade e de realeza cristã na formulação dessa noção na Gália do século VI. O autor apresentou os critérios de inclusão e exclusão que nortearam a elaboração identitária na região, bem como a sua relação com o deslocamento das fronteiras étnicas entre francos e galo-romanos. Esse autor estabeleceu um debate teórico sobre a noção de identidade baseando-se na análise interacionista de $\operatorname{Barth}^{79}$ e o conceito de microcristandade de Brown ${ }^{80}$. Embora se

\footnotetext{
${ }^{75}$ Bruno de Melo Oliveira. O senhor da guerra: relações políticas e sociais na vida do Cid Campeador. Niterói, 2006. 229 f. Dissertação (Mestrado em História Social) - Instituto de Ciências Humanas e Filosofia, Universidade Federal Fluminense, Niterói, 2006.

${ }^{76}$ Mônica Farias Fernández, A Senhor de Dom Afonso X: um estudo do paradigma mariano (Castela 1252-1284). Niterói, 1994. Dissertação (Dissertação em História Social) - Instituto de Ciências Humanas e Filosofia, Universidade Federal Fluminense, Niterói, 1994.

${ }^{77}$ Idem. Si tomas Los Dones que da la Sabiduría del Rey - a imagem de rei sábio de Afonso X (12521284). Niterói, 2000. Tese (Doutorado em História Social) - Instituto de Ciências Humanas e Filosofia, Universidade Federal Fluminense, Niterói, 2000.

${ }^{78}$ Edmar Checon de Freitas, Realeza e santidade na Gália Merovíngia: o caso dos "Decem Libri Historiarum” de Gregório de Tours (538-594). Niterói, 2004. Tese (Doutorado em História Social) Instituto de Ciências Humanas e Filosofia, Universidade Federal Fluminense, Niterói, 2004.

${ }^{79}$ Cf. As considerações sobre essa discussão em: Philippe Poutignat e Jocelyce Streife-Fernant, Teorias da Etnicidade: seguido de grupos étnicos e suas fronteiras de Fredrik Barth. São Paulo: Editora da Unesp, 1997.

${ }^{80}$ Cf. Peter Brown, El Primer Milenio de la Cristiandad Occidental. Barcelona: Crítica, 1997.
} 
baseasse nesses autores, Freitas propõe que o conceito de microcristandade seja ampliado de modo a incorporar a noção de fronteira étnica do primeiro autor trabalhado. Assim, o modelo gregoriano foi analisado à luz dos conflitos advindos da diversidade religiosa estudada através das atas dos concílios da Gália no século VI.

A questão relativa às concepções da realeza aparece em Luchsinger ${ }^{81}$ através do seu estudo sobre da Hispania visigótica de 568 a 636, período em que se organizou o Regnum de Toledo. Analisou-se Isidoro, bispo de Sevilha, que elaborou um modelo de realeza cristã. Nele, encontra-se a idéia chave de sanção divina atribuída à autoridade do soberano e legitimada pela Igreja de Roma. A historiadora tomou como fonte de investigação as Sententiae, a Historia Gothorum e as Etymologiae. Essa autora também estabeleceu um debate historiográfico com as proposições de Brown.

Vieira $^{82}$ analisou os gestos físicos do rei através da biografia de Carlos V de França (1337-1380) escrita por Christine de Pisan - Le Livre des Faits et Bonnes Meurs du Sage roi Charles $V$. Demonstrou por via de um rei paradigmático a relevância do controle do corpo e das emoções para o rei medieval. A temática da tese está circunscrita no âmbito das discussões realizadas na França pela Nova História. Além disso, destaca-se o fato de que o autor tenha tido a preocupação de apontar a relação entre a questão da gestualidade e a encenação do poder. Foi demonstrado que os gestos do rei, regulados por protocolos que começam a surgir nas cortes européias, eram um importante instrumento político do final da idade média. As circunstâncias em que este miroir aux princes foi escrito - uma encomenda da casa real para seus membros mostra a sua função de instrumento de propaganda política. Cabe destacar que não se trata de uma biografia desse rei. Na verdade, o autor confrontou o texto de Christine de Pisan com outras versões conhecidas da vida da personagem para compreender a sua transformação em um rei ideal. Por último, o autor destacou o contexto da guerra dos Cem Anos como um elemento para explicar a necessidade de afirmação da legitimidade da dinastia dos Valois.

\footnotetext{
${ }^{81}$ Maria Eugênia Mattos Luchsinger, A Pátria Gothorum de Isidourus Hispalensis: cultura e poder no reino Visigodo de Toledo (séculos VI-VII). Niterói, 2002. Dissertação (Mestrado em História Social) Instituto de Ciências Humanas e Filosofia, Universidade Federal Fluminense, Niterói. 2002.

${ }^{82}$ Francisco José Pereira das Neves Vieira, Carlos V da França: o Rei no espelho de Christine de Pisan. Niterói, 1999. Tese (Doutorado em História em Social) - Instituto de Ciências Humanas e Filosofia, Universidade Federal Fluminense, Niterói, 1999.
} 
Christine de Pisan também foi objeto da investigação de Schweinberger ${ }^{83}$, embora ela tenha dado uma ênfase à questão de gênero. A autora baseou-se no manual pedagógico Le Livre des Trois Vertus, escrito em 1405, para demonstrar a influência que o texto teve na corte de Avis uma vez que ele foi posteriormente traduzido para o português. Na realidade, tomou-se o Espelho de Cristina, impresso em Lisboa em 1518 a pedido de D. Leonor (1458-1525), para demonstrar como o paradigma da mulher virtuosa e cristã e, sobretudo, letrada encontrou solo fértil em Portugal e serviu como uma espécie manual de convivência palaciana do mundo cortesão.

Em relação à USP é importante sublinhar, que embora essa universidade tenha tido um papel fundamental na difusão da pós-graduação brasileira e tenha formado grande parte dos pesquisadores que atualmente realizam pesquisas em idade média pelo Brasil, nunca foi organizado um centro de pesquisa em história medieval. A sua produção sempre esteve e ainda está vinculada ao quadro de professores que atuam na sua pós-graduação.

Em 1942, Eurípedes Simões de Paula, sob a orientação de Jean Gage, defendeu a primeira tese brasileira sobre idade média na Universidade de São Paulo. Esta tese versava sobre o comércio varegue e o Grão-Principado de $\mathrm{Kiev}^{84}$. Obtendo, em 1946, o Provimento de Cátedra com a tese Marrocos e suas relações com a Ibéria na Antigüidade $^{85}$, Paula orientou várias dissertações e teses sobre o período medieval na USP. Tais trabalhos ${ }^{86}$ enfocavam as mais diversas temáticas, englobando desde teses sobre a medicina de Paracelso ${ }^{87}$ até o culto de amida no Japão medieval ${ }^{88}$. Infere-se,

\footnotetext{
${ }^{83}$ Maria Luisa Tomasi Schweinberger, A mulher no espelho de Cristina: estudo das representações femininas no final da Idade Média (séculos XV e XVI). Niterói/Marechal Cândido Rondon, 2002. Dissertação (Mestrado em História Social) - Instituto de Ciências Humanas e Filosofia, Universidade Federal Fluminense/Universidade Estadual do Oeste do Paraná, Niterói/Marechal Cândido Rondon. 2002.

${ }^{84}$ Eurípedes Simões de Paula, Comércio varegue e o Grão-Principado de Kiev. São Paulo, 1942. Tese (Doutorado em História) - Faculdade de Filosofia, Letras e Ciências Humanas, Universidade de São Paulo, São Paulo. 1942.

${ }^{85}$ Idem, Marrocos e suas relações com a Ibéria na Antigüidade. São Paulo, 1946. Tese (Provimento de Cátedra em História) - Faculdade de Filosofia, Letras e Ciências Humanas, Universidade de São Paulo, São Paulo. 1946.

${ }^{86}$ As referências e os resumos de algumas teses e dissertações produzidas na Universidade de São Paulo foram encontrados no Dedalus, banco de dados bibliográficos da USP/catálogo on-line das bibliotecas do $\mathrm{SIBi} / \mathrm{USP}$.

Disponível em <http://dedalus.usp.br:4500/ALEPH/por/USP/USP/DEDALUS/find-a?> Acesso em: 27 , 28 e 29 janeiro 2008.

${ }^{87}$ Maria Amélia Mascarenhas Dantes, Sobre a medicina de Paracelso. São Paulo, 1972. Tese (Doutorado em História) - Faculdade de Filosofia, Letras e Ciências Humanas, Universidade de São Paulo, São Paulo. 1972.
} 
através dos títulos disponibilizados nos catálogos, no que diz respeito a teses e dissertações sobre o Ocidente medieval, há uma preponderância de trabalhos que tratam de questões relacionadas à política e à Igreja ${ }^{89}$. Dentre todas as dissertações e teses orientadas por Paula, destacam-se, as teses de Victor Deodato da Silva e de José Roberto Almeida Mello e a dissertação e a tese de Nachman Falbel uma vez que esses historiadores se tornaram professores da Universidade de São Paulo e tiveram um papel importante na produção acadêmica, orientando muitos dos historiadores que, por sua vez, orientaram professores que, atualmente, lecionam história medieval nas universidades e participam de programas de pós-gradução.

Silva $^{90}$ produziu sua tese Legislação econômica e social consecutiva à peste negra de 1348 e sua significação no contexto da crise do fim da Idade Média em 1970 na USP. Oito anos depois, elaborou, também na USP, sua tese de Livre Docência Declínio da cavalaria e as transformações da nobreza no fim da Idade Média na Europa Ocidental $^{91}$. Dos dez trabalhos sobre idade média orientados por Silva, quanto à delimitação espacial, quatro são sobre Portugal, dois sobre Itália, um sobre Inglaterra/Itália, um parece ser sobre a Itália, um sobre a Península Ibérica e um sobre a França. Deve-se mencionar que, em relação aos dez, há informações mais precisas de apenas dois deles: Imaginário e realidade social nas crônicas de Fernão Lopes e $O$ poder feminino na Península Ibérica da Reconquista.

\footnotetext{
${ }^{88}$ Ricardo Mário Gonçalves, Considerações sobre o culto de amida no Japão medieval: um exemplo de consciência histórica no budismo japonês. São Paulo, 1971. Tese (Doutorado em História) - Faculdade de Filosofia, Letras e Ciências Humanas, Universidade de São Paulo, São Paulo. 1971.

${ }^{89}$ Alguns exemplos são:

Eduardo D'Oliveira França, Realeza em Portugal na Idade Média e as origens do absolutismo. São Paulo, 1945. Tese (Doutorado em História) - Faculdade de Filosofia, Letras e Ciências Humanas, Universidade de São Paulo, São Paulo. 1945.

José Afonso de Moraes Bueno Passos, Bonifácio VIII e Felipe, o Belo, de França. São Paulo, 1972. Tese (Doutorado em História) - Faculdade de Filosofia, Letras e Ciências Humanas, Universidade de São Paulo, São Paulo. 1972.

Maria Luiza Corassin, Quarta cruzada e o império colonial de Veneza. São Paulo, 1972. Dissertação (Mestrado em História) - Faculdade de Filosofia, Letras e Ciências Humanas, Universidade de São Paulo, São Paulo. 1972.

${ }_{90}$ Victor Deodato Silva, da. Legislação econômica e social consecutiva à peste negra de 1348 e sua significação no contexto da crise do fim da Idade Média. São Paulo, 1970. Tese (Doutorado em História) - Faculdade de Filosofia, Letras e Ciências Humanas, Universidade de São Paulo, São Paulo. 1970.

${ }^{91}$ Idem, Declínio da cavalaria e as transformações da nobreza no fim da Idade Média na Europa Ocidental. São Paulo, 1978. Tese (Livre Docência em História) - Faculdade de Filosofia, Letras e Ciências Humanas, Universidade de São Paulo, São Paulo. 1978.
} 
Dos quatro trabalhos sobre Portugal, dois dizem respeito à dinastia de Borgonha Governo de D. Fernando I, o Formoso, de Portugal: suas pretensões à coroa castelhana e suas conseqüências na política portuguesa ${ }^{92}$ e D. Dinis, o Pai da pátria, de Portugal: a formação de uma imagem, as suas realizações político-diplomáticas e suas repercussões ${ }^{93}$ - e dois estão cronologicamente relacionados à dinastia de Avis - Rei como fonte de justiça nas crônicas de Fernão Lopes ${ }^{94}$ e Imaginário e realidade social nas crônicas de Fernão Lopes ${ }^{95}$. Esse último, composto por seis capítulos, propõe-se a retratar o imaginário e a realidade social nas crônicas de Fernão Lopes tendo como objeto de análise a concepção de história, o uso do nome de Deus e as manifestações da presença divina, as cerimônias pertinentes aos pilares das relações sócio-políticas de onde se destacam as coroações, a armação do cavaleiro e o julgamento de fidelidade, o casamento e suas modalidades marginais, as principais manifestações sentimentais do homem medieval português e os grupos marginalizados na obra de Lopes.

Os dois trabalhos sobre Itália distanciam-se tanto temática quanto cronologicamente. Um trata da Puglia e sua relação com o domínio exercido pelo reino de Aragão no final do século XV e início do $\mathrm{XVI}^{96}$ e o outro versa sobre o século XII, sobre o universo leigo e o eclesiástico nos Concílios de Latrão I, II e III ${ }^{97}$.

\footnotetext{
${ }^{92}$ Antônio Luiz Lachi, Governo de D. Fernando I, o Formoso, de Portugal: suas pretensões a coroa castelhana e suas conseqüências na política portuguesa. São Paulo, 1982. Dissertação (Mestrado em História) - Faculdade de Filosofia, Letras e Ciências Humanas, Universidade de São Paulo, São Paulo. 1982.

${ }^{93}$ Idem, D. Dinis, o Pai da pátria, de Portugal: a formação de uma imagem, as suas realizações políticodiplomáticas e suas repercussões. São Paulo, 1994. Tese (Doutorado em História) - Faculdade de Filosofia, Letras e Ciências Humanas, Universidade de São Paulo, São Paulo. 1994.

94 Valentim Biasotto, Rei como fonte de justiça nas crônicas de Fernão Lopes. São Paulo, 1982. Dissertação (Mestrado em História) - Faculdade de Filosofia, Letras e Ciências Humanas, Universidade de São Paulo, São Paulo. 1982.

${ }^{95}$ Idem, Imaginário e realidade social nas crônicas de Fernão Lopes. São Paulo, 1995. Tese (Doutorado em História) - Faculdade de Filosofia, Letras e Ciências Humanas, Universidade de São Paulo, São Paulo. 1995.

${ }^{96}$ Braz Francisco Raul Santiago Winkler Pepe, Puglia aragonese: reações e compromissos ao domínio real: 1442-1516. São Paulo, 1981. Tese (Doutorado em História) - Faculdade de Filosofia, Letras e Ciências Humanas, Universidade de São Paulo, São Paulo. 1981.

${ }^{97}$ DIAS, Ivone Marques. Universo eclesiástico e o universo leigo nos Concílios de Latrão I, II e III do século XII. São Paulo, 1985. Tese (Doutorado em História) - Faculdade de Filosofia, Letras e Ciências Humanas, Universidade de São Paulo, São Paulo. 1985.
} 
A dissertação Viagens de Chaucer à Itália de Neto ${ }^{98}$ aborda as viagens desse inglês. Para esse autor, a Inglaterra e a Itália constituem a delimitação espacial da tese ${ }^{99}$, que trata do interesse inglês pela Sicília e a visão sobre a Itália presente nos escritos dos viajantes ingleses dos séculos XII e XIII.

Sobre a França, Victor Deodato da Silva orientou a dissertação defendida em 1978 Margarida de Provença: interesses familiares e política ${ }^{100}$, cujo título parece remeter a uma história política vista a partir de um personagem feminino, Margarida de Provença, a mulher de Luís IX, São Luís. Quase vinte anos depois, em 2000, foi defendido outro trabalho que enfocava a questão da mulher e do poder. Foi a tese $O$ poder feminino na Península Ibérica da Reconquista da professora Maria do Carmo Santos ${ }^{101}$ da Universidade Estadual do Rio de Janeiro. Tal tese analisa a posição ocupada pelas rainhas ibéricas nos diversos reinos peninsulares durante a guerra de Reconquista, em especial, procura compreender de que maneira e em que medida estas mulheres participaram do poder político e de que forma os cronistas percebiam o papel desempenhado por elas nestes episódios.

Com a orientação de Simões de Paula, Mello ${ }^{102}$ defendeu em 1972 a tese Insularização da monarquia angevina e a formação da nação inglesa: séculos XIII e XV, vistos através de canções e poemas políticos. Como professor da USP e ainda trabalhando com a Inglaterra medieval, Mello ${ }^{103}$ defendeu, em 1980, a tese de Livre Docência: Duas faces de um soberano: Ricardo II na literatura de seu tempo. Em 1993, orientou a tese

\footnotetext{
98 Jônatas Batista Neto, Viagens de Chaucer à Itália. São Paulo, 1975. Dissertação (Mestrado em História) - Faculdade de Filosofia, Letras e Ciências Humanas, Universidade de São Paulo, São Paulo. 1975.

${ }^{99}$ Idem, Interesse inglês pela Sicília e a imagem da Itália nos textos de viajantes britânicos dos séculos XII e XIII. São Paulo, 1978. Tese (Doutorado em História) - Faculdade de Filosofia, Letras e Ciências Humanas, Universidade de São Paulo, São Paulo. 1978.

100 Ísis Garcia Salvestro, Margarida de Provença: interesses familiares e política. São Paulo, 1978. Dissertação (Mestrado em História) - Faculdade de Filosofia, Letras e Ciências Humanas, Universidade de São Paulo, São Paulo. 1978.

${ }^{101}$ Maria do Carmo Parente Santos, O poder feminino na Península Ibérica da Reconquista. São Paulo, 2000. Tese (Doutorado em História) - Faculdade de Filosofia, Letras e Ciências Humanas, Universidade de São Paulo, São Paulo. 2000.

${ }_{102}$ José Roberto de Almeida Mello, Insularização da monarquia angevina e a formação da nação inglesa: séculos XIII e XV, vistos através de canções e poemas políticos. São Paulo, 1972. Tese (Doutorado em História) - Faculdade de Filosofia, Letras e Ciências Humanas, Universidade de São Paulo, São Paulo. 1972.

${ }^{103}$ Idem, Duas faces de um soberano: Ricardo II na literatura de seu tempo. São Paulo, 1980. Tese (Livre Docência em História) - Faculdade de Filosofia, Letras e Ciências Humanas, Universidade de São Paulo, São Paulo. 1980.
} 
Tolosanos, cátaros e faidits: conflitos sociais e resistência armada no Langue-doc durante a Cruzada Albingense de José Rivair Macedo ${ }^{104}$, atualmente professor da Universidade Federal do Rio Grande do Sul, UFRGS. No seu trabalho, Macedo realizou uma reflexão sobre a contribuição da produção historiográfica da França no que diz respeito às questões sociais do Languedoc no século XIII, mais especificamente, sobre o momento da cruzada albigense. Além disso, tomando como fontes primárias crônicas e poemas daquela época, analisou a articulação do fenômeno da heresia com as camadas sociais do Languedoc no desencadeamento, desenvolvimento e repressão do catarismo. Tal articulação foi examinada a partir de dois movimentos: a ligação da aristocracia rural com o catarismo e a relação do grupo que tinha o controle dos órgãos municipais da cidade Tolosa com os ministros cátaros. Buscando eliminar os cátaros, os representantes da Igreja dominaram a nobreza rural, através da expropriação de seus bens e direitos, fazendo com que os nobres que tinham relações com o catarismo se transformassem em faidits e derrotaram a resistência de Tolosa com o objetivo de substituir o patriciado que controlava esta cidade. O cerne de sua tese é composto pelo estudo dos modos de resistência dos habitantes de Tolosa à investidas das forças a serviço da Igreja assim como da associação entre faidits e tolosanos entre 1209 e 1224, que teve como conseqüência a vitória temporária daqueles que defendiam o catarismo.

Nachman Falbel teve sua dissertação e sua tese orientadas por Simões de Paula. Defendida em 1969, sua dissertação ${ }^{105}$ versava sobre as heresias dos séculos XII e XIII. Sua tese, datada de 1972, intitulou-se Luta dos espirituais e sua contribuição para a reformulação da teoria tradicional acerca do poder papal ${ }^{106}$. Em 1977, obteve a Livre Docência na USP com a tese Arnaldo de Vilanova, sua doutrina reformista e sua concepção escatológica ${ }^{107}$. Das vinte e oito teses e dissertações que orientou, dezesseis são sobre Idade Média. Estudando, principalmente, questões relacionadas à religião, a

\footnotetext{
${ }^{104}$ José Rivair Macedo. Tolosanos, cátaros e faidits: conflitos sociais e resistência armada no Languedoc durante a Cruzada Albingense. São Paulo, 1993. Tese (Doutorado em História) - Faculdade de Filosofia, Letras e Ciências Humanas, Universidade de São Paulo, São Paulo. 1993.

${ }^{105}$ Nachman Falbel, Heresias dos séculos XII e XIII. São Paulo, 1969. Dissertação (Mestrado em História) - Faculdade de Filosofia, Letras e Ciências Humanas, Universidade de São Paulo, São Paulo. 1969.

${ }^{106}$ Idem, Luta dos espirituais e sua contribuição para a reformulação da teoria tradicional acerca do poder papal. São Paulo, 1972. Tese (Doutorado em História) - Faculdade de Filosofia, Letras e Ciências Humanas, Universidade de São Paulo, São Paulo. 1972.

${ }^{107}$ Idem. Arnaldo de Vilanova, sua doutrina reformista e sua concepção escatológica. São Paulo, 1977. Tese (Livre Docência em História) - Faculdade de Filosofia, Letras e Ciências Humanas, Universidade de São Paulo, São Paulo. 1977.
} 
maior parte dos dezesseis trabalhos que Falbel orientou trata, de alguma forma, daquela temática.

Sete estudos supervisionados por Falbel fundamentam-se em pensadores de grande relevância para o medievo. A filosofia política de Guilherme de Ockham foi tema da dissertação $^{108}$ e da tese ${ }^{109}$ de Souza. Em 1980, Utimura ${ }^{110}$, analisou, na sua dissertação, a concepção de São Bernardo de Claraval sobre o poder espiritual e, no ano seguinte, Lejbman $^{111}$ defendeu uma dissertação sobre Egidio Romano e seu tratado De Ecclesiastica Potestatae. A obra Sacramental de Clemente Sanchez foi objeto de análise de Horch $^{112}$ em tese de 1985. Um intervalo de quase vinte anos separa a tese de Horch de um trabalho baseado na obra de um determinado pensador. A retomada de estudos de tal natureza se deu com a tese, defendida em 2003, da professora Ana Paula Tavares Magalhães ${ }^{113}$ da USP. Em Contribuição à questão da pobreza presente na obra Arbor Vitae Crucifixae Iesu, de Ubertino de Casale, Magalhães aborda a questão da pobreza tal como ela é concebida na principal obra do frade franciscano Ubertino de Casale (1259-c.1328), a Arbor vitae crucifixae Iesu. Para Casale, o voto de pobreza deveria ser rigorosamente observado, sendo imposta uma série de normas extremamente rigorosas e tendo como referência fundamental o usus pauper. Em 2004, também foi defendida uma tese ${ }^{114}$ sobre um pensador medieval. Parece que, com Santo Tomás de Aquino e a fronteira histórica entre a fé e a razão, Palma procura tratar das conseqüências da condenação do aristotelismo em 1277 para o pensamento tomista, isto

\footnotetext{
108 José Antônio de Camargo Rodrigues Souza, Conceito de plenitude potestati na filosofia politica de Guilherme de Ockham. São Paulo, 1975. Dissertação (Mestrado em História) - Faculdade de Filosofia, Letras e Ciências Humanas, Universidade de São Paulo, São Paulo. 1975.

109 Ibide,. Contribuição filosófico-politica de Guilherme de Ockham ao conceito de poder civil. São Paulo, 1980. Tese (Doutorado em História) - Faculdade de Filosofia, Letras e Ciências Humanas, Universidade de São Paulo, São Paulo. 1980.

${ }^{110}$ Nancy Utimura. São Bernardo de Claraval e sua concepção sobre o poder espiritual. São Paulo, 1980. Dissertação (Mestrado em História) - Faculdade de Filosofia, Letras e Ciências Humanas, Universidade de São Paulo, São Paulo. 1980.

${ }^{111}$ Raymunda Clea Pett Brandao Goldman Vel. Lejbman Egídio Romano e De Ecclesiastica Potestatae. São Paulo, 1981. Dissertação (Mestrado em História) - Faculdade de Filosofia, Letras e Ciências Humanas, Universidade de São Paulo, São Paulo. 1981.

${ }^{112}$ Rosemarie Érika Horch, Luzes e fogueiras, dos albores da imprensa ao obscurantismo da inquisição no Sacramental de Clemente Sanchez. São Paulo, 1985. Tese (Doutorado em História) - Faculdade de Filosofia, Letras e Ciências Humanas, Universidade de São Paulo, São Paulo. 1985.

113 Ana Paula Tavares Magalhães. Contribuição à questão da pobreza presente na obra Arbor Vitae Crucifixae Iesu, de Ubertino de Casale. São Paulo, 2003. Tese (Doutorado em História) - Faculdade de Filosofia, Letras e Ciências Humanas, Universidade de São Paulo, São Paulo. 2003.

${ }^{114}$ Laura Pinca da Palma, Santo Tomás de Aquino e a fronteira histórica entre a fé e a razão. São Paulo, 2004. Dissertação (Mestrado em História) - Faculdade de Filosofia, Letras e Ciências Humanas, Universidade de São Paulo, São Paulo. 2004.
} 
é, a desestruturação da harmonia tomista entre fé e razão, que auxiliou o desenvolvimento do racionalismo renascentista.

A relação de ordens monásticas com a formação do Estado português foi estudada por Galli no mestrado ${ }^{115}$ e no doutorado ${ }^{116}$. Sua dissertação, defendida em 1979, versa sobre a relação das ordens de Cluny e de Cister com a formação de Portugal enquanto que sua tese, de 1983, focaliza o papel Cister na constituição daquele Estado.

Ainda no âmbito dos trabalhos que se relacionam com o tema da religião, encontra-se a dissertação de Magalhães ${ }^{117}$. Defendida em 1998, trata da questão espiritual dos beguinos da região da Provença.

Três estudos orientados por Falbel abordam a questão dos judeus nos reinos de Navarra e Leão e Castela. O primeiro, de 1976, foi a dissertação Política do reino de Navarra a partir do reino de Carlos II em relação aos judeus até o ano de 1391 de Sanchez ${ }^{118}$ que, em 1981, defendeu a tese Contribuição ao estudo dos Judeus em Navarra durante a Idade Media $^{119}$. Neste mesmo ano, ocorreu a defesa da tese de Silva ${ }^{120}$, que se intitula Crítica e autocrítica das cortes reais e nobres de Leão e Castela na época de Afonso, o Sábio: o caso particular dos judeus nos cancioneiros galaico-portugueses.

\footnotetext{
${ }^{115}$ Sidinei. Galli, Ordens monásticas Cluny e Cister na formação do Estado português. São Paulo, 1979. Dissertação (Mestrado em História) - Faculdade de Filosofia, Letras e Ciências Humanas, Universidade de São Paulo, São Paulo. 1979.

${ }^{116}$ Idem, Monaquismo cisterciense na formação do Estado português. São Paulo, 1983. Tese (Doutorado em História) - Faculdade de Filosofia, Letras e Ciências Humanas, Universidade de São Paulo, São Paulo. 1983.

117 Ana Paula Tavares Magalhães, A questão espiritual nos beguinos da Provença. São Paulo, 1998. Dissertação (Mestrado em História) - Faculdade de Filosofia, Letras e Ciências Humanas, Universidade de São Paulo, São Paulo. 1998.

${ }_{11}$ Maria Guadalupe Pedrero Sanchez, Política do reino de Navarra a partir do reino de Carlos II em relação aos judeus até o ano de 1391. São Paulo, 1976. Dissertação (Mestrado em História) - Faculdade de Filosofia, Letras e Ciências Humanas, Universidade de São Paulo, São Paulo. 1976.

${ }^{119}$ Idem. Contribuição ao estudo dos Judeus em Navarra durante a Idade Média. São Paulo, 1981. Tese (Doutorado em História) - Faculdade de Filosofia, Letras e Ciências Humanas, Universidade de São Paulo, São Paulo. 1981.

${ }^{120}$ Olga Mussi da Silva, Crítica e autocrítica das cortes reais e nobres de Leão e Castela na época de Afonso, o Sábio: o caso particular dos judeus nos cancioneiros galaico-portugueses. São Paulo, 1981. Tese (Doutorado em História) - Faculdade de Filosofia, Letras e Ciências Humanas, Universidade de São Paulo, São Paulo. 1981.
} 
Os trabalhos Relações conjugais e extraconjugais na alta nobreza portuguesa no final do século XIV e inicio do século XV de Feldman ${ }^{121}$, A arte da guerra no século XII: as campanhas italianas de Frederico I Barbarossa (1154-1162) de Araújo ${ }^{122}$ e O rei, o guerreiro e o herói: Beowulf e sua representação no mundo germânico de Medeiros ${ }^{123}$ tiveram também a orientação de Falbel. A respeito da dissertação de Feldman, não existem no banco de dados bibliográficos da USP, o Dedalus ${ }^{124}$, maiores informações disponíveis.

A dissertação de Araújo tem como objetivo estudar a arte da guerra no século XII por meio das duas primeiras campanhas italianas de Frederico I Barbarossa contra as comunas lombardas (1154-5 e 1158-62). Isto é, o autor enfoca a guerra como parte imprescindível do desenvolvimento da civilização no século XII, afetando e integrando várias esferas como a Cultura, a Tecnologia, a Política, a Economia e a Sociedade. Assim, percebe que a guerra se insere no conceito medieval de Arte, Ars, isto é, a técnica do fazer. A dissertação de Medeiros examina o poema Beowulf e sua relevância na sociedade da Inglaterra anglo-saxônica, principalmente, no que tange às imagens régias e aristocráticas. Segundo Medeiros, o poema Beowulf e outras obras de caráter heróico teriam um objetivo modelar para a aristocracia guerreira no momento da reconquista dos territórios ocupados pelos escandinavos desde o começo das primeiras invasões. As imagens presentes naquelas obras e, de forma especial, no Beowulf, espelhariam um ideal aristocrático germânico. Contudo, tal ideal era profundamente influenciado pela tradição cristã.

Conforme exposto acima, após ter sido orientado em suas dissertação e tese por Victor Deodato da Silva na USP, o professor Jônatas Batista Neto da Universidade do Estado de São Paulo defendeu, também nesta universidade, sua tese de livre docência, Guelfos

\footnotetext{
${ }^{121}$ Sérgio Alberto Feldman, Relações conjungais e extraconjugais na alta nobreza portuguesa no final do século XIV e início do século XV. São Paulo, 1986. Dissertação (Mestrado em História) - Faculdade de Filosofia, Letras e Ciências Humanas, Universidade de São Paulo, São Paulo. 1986.

${ }^{122}$ Vinícius César Dreger de Araújo, A arte da guerra no século XII: as campanhas italianas de Frederico I Barbarossa (1154-1162). São Paulo, 2004. Dissertação (Mestrado em História) - Faculdade de Filosofia, Letras e Ciências Humanas, Universidade de São Paulo, São Paulo. 2004.

${ }^{123}$ Elton Oliveira Souza de Medeiros, O rei, o guerreiro e o herói: Beowulf e sua representação no mundo germânico. São Paulo, 2006. Dissertação (Mestrado em História) - Faculdade de Filosofia, Letras e Ciências Humanas, Universidade de São Paulo, São Paulo. 2006.

${ }^{124}$ Disponível em < http://dedalus.usp.br:4500/ALEPH/POR/USP/USP/TES/FULL/0719667? > Acesso em: 28 janeiro 2008.
} 
e gibelinos em Florença ${ }^{125}$, em 1985. Dentre as onze teses e dissertações orientadas por Batista Neto, seis são sobre Idade Média ocidental. Destas seis, três têm como recorte espacial a França, uma trata de Portugal, uma tem Florença como delimitação e uma, pela escassa informação disponível, não se pôde delimitar com certeza o seu recorte espacial. Para tanto, seria necessário acessar o catálogo analógico da USP.

A França é a delimitação espacial da dissertação aprovada em 1994, Religiosidade, mentalidades e representações na Idade Média: os demônios e os mortos no De vita sua de Gilbert de Nogent (1055-1125) de Morás ${ }^{126}$. Rimoli ${ }^{127}$, usando como fontes primárias os Lais de Marie de France, analisou, na dissertação defendida em 1996, os tipos femininos do imaginário medieval. Na tese As múltiplas facetas de Alexandre Magno no "Roman d'Alexandre"128 de 2001, Custódio procura, a partir da adaptação do mito de Alexandre à realidade francesa do século XII, indicar alguns aspectos do imaginário presentes na Idade Média.

Em relação a Portugal, Jônatas Batista Neto orientou a dissertação de Megiani ${ }^{129}$, Jovem rei encantado: aspectos da construção e personificação do mito messiânico português, segundo as informações do Dedalus ${ }^{130}$.

A tese de Biason ${ }^{131}$ tem a mesma delimitação espacial da tese de livre docência do seu orientador: Florença. Defendida em 1998, a tese Decadência e corrupção na história de Florença: a visão de Nicolau Maquiavel, ao analisar a última produção do autor,

125 Jônatas Batista Neto, Guelfos e gibelinos em Florença. São Paulo, 1985. Tese (Livre Docência em História) - Faculdade de Filosofia, Letras e Ciências Humanas, Universidade de São Paulo, São Paulo. 1985.

${ }^{126}$ Antônio Pasqual Vicente Moras, Religiosidade, mentalidades e representações na Idade Média: os demônios e os mortos no "De vita sua" de Gilbert de Nogent (1055-1125). São Paulo, 1994. Dissertação (Mestrado em História) - Faculdade de Filosofia, Letras e Ciências Humanas, Universidade de São Paulo, São Paulo. 1994.

${ }^{127}$ Maria Thereza Rimoli, Os tipos femininos do imaginário medieval nos Lais de Marie de France. São Paulo, 1996. Dissertação (Mestrado em História) - Faculdade de Filosofia, Letras e Ciências Humanas, Universidade de São Paulo, São Paulo. 1996.

${ }^{128}$ Pedro Prado Custódio, As múltiplas facetas de Alexandre Magno no "Roman d'Alexandre". São Paulo, 2001. Tese (Doutorado em História) - Faculdade de Filosofia, Letras e Ciências Humanas, Universidade de São Paulo, São Paulo. 2001.

${ }^{129}$ Ana Paula Torres Megiani, Jovem rei encantado: aspectos da construção e personificação do mito messiânico português. São Paulo, 1995. Dissertação (Mestrado em História) - Faculdade de Filosofia, Letras e Ciências Humanas, Universidade de São Paulo, São Paulo. 1995.

${ }^{130}$ Disponível em < http://dedalus.usp.br:4500/ALEPH/POR/USP/USP/TES/FULL/0741636? > Acesso em: 28 janeiro 2008.

${ }^{131}$ Rita de Cássia Aparecida Biason, Decadência e corrupção na história de Florença: a visão de Nicolau Maquiavel. São Paulo, 1998. Tese (Doutorado em História) - Faculdade de Filosofia, Letras e Ciências Humanas, Universidade de São Paulo, São Paulo. 1998. 
História de Florença, procura, com o estudo do pensamento histórico de Maquiavel, ajudar na compreensão do seu pensamento político.

Levando em consideração as concepções desenvolvidas período feudal, Morás ${ }^{132}$, em Os entes sobrenaturais na Idade Média: imaginário, representações e formas de ordenamento social no período tem como objetivo compreender o significado dos entes sobrenaturais - fadas, anjos, demônios, santos dentre outros - que são admitidos pela cultura do medievo e entender a forma pela qual as propriedades e as características daqueles entes contribuem para os modelos de ordem social da época.

Após a elaboração, na Universidade de São Paulo, de uma tese ${ }^{133}$ que se insere cronologicamente na modernidade, o professor Carlos Roberto Figueiredo Nogueira defendeu na USP, em 1993, sua tese de Livre Docência intitulada Nascimento da bruxaria: da identificação do inimigo a diabolização de seus agentes ${ }^{134}$ na qual se aprofunda em assuntos ligados à Idade Média. Das dezoito teses e dissertações orientadas pelo professor Nogueira, cinco tratam explicitamente do período medieval. Destaca-se a dissertação de Nogueira ${ }^{135}$, Do homem ao Cristo: o espaço-tempo na construção da imagem de São Francisco de Assis, defendida em 1997, também tenha como recorte cronológico a Idade Média.

Pereira $^{136}$ defendeu, em 1996, a dissertação Herói e o soberano: modelo heróico e representações da soberania na Demanda do Santo Graal. Dois anos depois, Vereza ${ }^{137}$

\footnotetext{
${ }^{132}$ Antonio Pasqual Vicente Morás. Os entes sobrenaturais na Idade Média: imaginário, representações e formas de ordenamento social no periodo. São Paulo, 2000. Tese (Doutorado em História) - Faculdade de Filosofia, Letras e Ciências Humanas, Universidade de São Paulo, São Paulo. 2000.

${ }^{133}$ Carlos Roberto Figueiredo Nogueira, Universo mágico e realidade: aspectos de um contexto cultural: Castela na modernidade. São Paulo, 1980. Tese (Doutorado em História) - Faculdade de Filosofia, Letras e Ciências Humanas, Universidade de São Paulo, São Paulo. 1980.

${ }^{134}$ Carlos Roberto Figueiredo Nogueira, Nascimento da bruxaria: da identificação do inimigo a diabolização de seus agentes. São Paulo, 1993. Tese (Livre Docência em História) - Faculdade de Filosofia, Letras e Ciências Humanas, Universidade de São Paulo, São Paulo. 1993.

${ }^{135}$ Ieda Maria Silveira Fleury Nogueira. Do homem ao Cristo: o espaço-tempo na construção da imagem de São Francisco de Assis. São Paulo, 1997. Dissertação (Mestrado em História) - Faculdade de Filosofia, Letras e Ciências Humanas, Universidade de São Paulo, São Paulo. 1997.

${ }^{136}$ Rita de Cássia Mendes Pereira, Herói e o soberano: modelo heróico e representações da soberania na Demanda do Santo Graal. São Paulo, 1996. Dissertação (Mestrado em História) - Faculdade de Filosofia, Letras e Ciências Humanas, Universidade de São Paulo, São Paulo. 1996.

${ }^{137}$ Renata Vereza, Visões do inimigo: imagens de mouros em Castela no século XIII. São Paulo, 1998. Dissertação (Mestrado em História) - Faculdade de Filosofia, Letras e Ciências Humanas, Universidade de São Paulo, São Paulo. 1998.
} 
apresentou a dissertação Visões do inimigo: imagens de mouros em Castela no século XIII.

Sob a orientação de Nogueira, foi aprovada em 2003 a tese de Pereira e, em 2004, foram defendidas as teses de Visalli e de Jayo. No trabalho intitulado Práticas de magia e agentes mágicos no cotidiano e nas representações sociais da cavalaria (séculos XII e XIII), Pereira ${ }^{138}$, aborda a presença da magia nos romans arturianos em verso e em prosa, elaborados nos séculos XII e XIII. Segundo a autora, essa presença indica a grande circulação nos ambientes nobiliárquicos de determinadas heranças culturais e formas de expressão religiosa divergentes daquelas que eram defendidas pelos cânones eclesiásticos, uma forte tolerância a essas tradições, e uma ambivalência da cultura clerical no que diz respeito aos agentes mágicos e à magia. Desta forma, mesmo que subordinados aos projetos literários demandados pelo seu público e seus patrocinadores, os clérigos-escritores dos romans de cavalaria eram bastante condicionados pelas analogias e identidades entre os valores da cultura clerical hegemônica e os diferentes modelos culturais que guiavam a composição de suas obras.

Visalli ${ }^{139}$ em Cantando até que a morte nos salve: estudo sobre laudas italianas dos séculos XIII e XIV, procura mostrar que, apesar do caráter pessoal de várias laudas do poeta franciscano Jacopone de Todi, sua produção estava inserida no conjunto das laudas, expressões religiosas populares destinadas ao canto coral e que, em sua grande maioria, eram anônimas e compostas em língua vulgar. Perda e salvação da Espanha no imaginário castelhano: a invasão muçulmana na Península Ibérica de Jayo ${ }^{140}$ tem como objeto as diversas visões que, com o passar do tempo, os cristãos tiveram do desembarque islâmico de 711 e da formação de um núcleo rebelde ao governo muçulmano nas montanhas de Astúrias. Inicialmente, a historiadora trata da apreensão, ocorrida apenas no século XI, por parte dos autores cristãos da versão lendária da invasão muçulmana, que já era veiculada por fontes árabes, apontando, assim, para a

\footnotetext{
138 Rita de Cássia Mendes Pereira, Práticas de magia e agentes mágicos no cotidiano e nas representações sociais da cavalaria (séculos XII e XIII). São Paulo, 2003. Tese (Doutorado em História) - Faculdade de Filosofia, Letras e Ciências Humanas, Universidade de São Paulo, São Paulo. 2003.

${ }^{139}$ Angelita Marques Visalli, Cantando até que a morte nos salve: estudo sobre laudas italianas dos séculos XIII e XIV. São Paulo, 2004. Tese (Doutorado em História) - Faculdade de Filosofia, Letras e Ciências Humanas, Universidade de São Paulo, São Paulo. 2004.

${ }^{140}$ Graciela Mérida de Jayo, Perda e salvação da Espanha no imaginário castelhano: a invasão muçulmana na Península Ibérica. São Paulo, 2004. Tese (Doutorado em História) - Faculdade de Filosofia, Letras e Ciências Humanas, Universidade de São Paulo, São Paulo. 2004.
} 
influência árabe nas fontes cristãs. No século XV, quando o muçulmano estava vencido, suas virtudes passaram a ser idealizadas. No século posterior, a versão lendária mostra que o período de ocupação muçulmana não teve grandes conseqüências e foi superado pela Reconquista.

Hilário Franco Júnior defendeu sua tese de Livre Docência intitulada Ensaios de mitologia medieval $^{141}$ em 1993, na USP, onde lecionava. Nesta mesma universidade, orientou, segundo a seção "orientações" do seu currículo que se encontra na Plataforma Lattes $^{142}$, site do CNPq, e o banco de dados bibliográficos da USP, Dedalus ${ }^{143}$, três dissertações e sete teses.

Sob sua orientação, Almeida ${ }^{144}$ defendeu, em 2001, a dissertação O pecado original na escultura romântica da Borgonha - séculos XI e XII, que é um estudo sobre o imaginário relacionado à moral sexual e ao Pecado. Em quatro imagens românicas do Pecado Original esculpidas em quatro igrejas da Borgonha, na França, as figuras de Eva - Maria - Madalena participavam no processo de Pecado/ Salvação dos fiéis. Tais imagens, que se relacionavam com o ideal penitencial veiculado pela ordem cluniacense, faziam parte da liturgia desenvolvida naquelas igrejas. Em 2002, foi aprovada a dissertação Navigatio Sancti Brendani Abbatis: tempo, espaço, outro mundo e peregrinação no relato da viagem de São Brandão à terra repromissionis de Asfora $^{145}$. Neste trabalho, Asfora procura compreender o motivo do grande sucesso do Navigatio Sancti Brendani Abbatis. Busca o sentido histórico dessa narrativa inserindoo e analisando-o com base no contexto do período no qual foi elaborado. Fundamentando-se em quatro categorias analíticas - a peregrinação e as idéias de espaço, de tempo e de Outro Mundo - a historiadora localizou os sentimentos e as idéias

${ }^{141}$ Hilário Franco Júnior, Ensaios de mitologia medieval. São Paulo, 1993. Tese (Livre Docência em História) - Faculdade de Filosofia, Letras e Ciências Humanas, Universidade de São Paulo, São Paulo. 1993.

${ }_{142}$ Disponível em $<$ http://buscatextual.cnpq.br/buscatextual/index.jsp $>$ Acesso em: 29 janeiro 2008.

143 Disponível em <http://dedalus.usp.br:4500/ALEPH/por/USP/USP/DEDALUS/FIND$\mathrm{A}$ ?FIND $=$ Todos $\&$ BASE $=$ Teses + USP $\&$ VALUE $=$ FRANCO $+\mathrm{J} \%$ DANIOR $\% 2 \mathrm{C}+\mathrm{Hil} \%$ E1rio $>$ Acesso em: 29 janeiro 2008.

${ }^{144}$ Vivian Patrícia Cariello Coutinho de Almeida, O pecado original na escultura romântica da Borgonha - séculos XI e XII. São Paulo, 2001. Dissertação (Mestrado em História) - Faculdade de Filosofia, Letras e Ciências Humanas, Universidade de São Paulo, São Paulo. 2001.

145 Wanessa Colares Asfora, Navigatio Sancti Brendani Abbatis: tempo, espaço, outro mundo e peregrinação no relato da viagem de São Brandão à terra repromissionis. São Paulo, 2002. Dissertação (Mestrado em História) - Faculdade de Filosofia, Letras e Ciências Humanas, Universidade de São Paulo, São Paulo. 2002. 
nas quais os textos se inserem e comprovou o papel da linguagem, construção e organização formal do texto na transmissão de significados que só se tornam compreensíveis se relacionados aos códigos culturais nos quais o texto se filia.

$\mathrm{Na}$ dissertação Intento sensu et vigilanti mente: esboço de uma problemática histórica do som no Ocidente medieval ${ }^{146}$, defendida em 2007, Aubert apresenta a forma como o som sofreu processos de 'semantização' discutindo as transformações histórias das formas de apreensão do som pelo pensamento. Na segunda parte da dissertação, o autor expôs o processo de enformação do som por meio da análise da liturgia latina. Por fim, ele trouxe um estudo de caso através do qual a dinâmica entre os processos de semantização da forma sonora e o de enformação sonora do conteúdo.

Em 1997, Franco Júnior orientou a tese Imagem e Reflexo: religiosidade e monarquia no reino visigodo de Toledo (séculos VI e VII) de Andrade Filho ${ }^{147}$, professor da Universidade Estadual Paulista Júlio Mesquita Filho, UNESP. A tese de Souza ${ }^{148}$, professora da Universidade Estadual de Campinas, UNICAMP, A Cristianização dos mortos: a mensagem evangelizadora da Legenda Áurea de Jacopo de Varazze foi defendida em 1998. Foi aprovada, em 1999, a tese Topologia da mentalidade medieval: reflexões de Teixeira ${ }^{149}$.

Em 2002, Machado ${ }^{150}$, teve a sua tese, Da visão teológico-antropocêntrica nas Cantigas de Santa Maria: um estudo sobre a concepção medieval e cristã da História aprovada. A tese trata do estudo da concepção medieval e cristã da História por meio de sua representação nas Cantigas de Santa Maria. A partir de uma perspectiva semântica, Machado aprofunda o estudo das Cantigas no plano subjacente do discurso e encontra

\footnotetext{
${ }^{146}$ Eduardo Henrik Aubert, Intento sensu et vigilanti mente: esboço de uma problemática histórica do som no Ocidente medieval. São Paulo, 2007. Dissertação (Mestrado em História) - Faculdade de Filosofia, Letras e Ciências Humanas, Universidade de São Paulo, São Paulo. 2007.

${ }^{147}$ Ruy de Oliveira Andrade Filho, Imagem e Reflexo: religiosidade e monarquia no reino visigodo de Toledo (séculos VI e VII). São Paulo, 1997. Tese (Doutorado em História) - Faculdade de Filosofia, Letras e Ciências Humanas, Universidade de São Paulo, São Paulo. 1997.

148 SOUZA, Néri de Almeida Souza, A cristianização dos mortos: a mensagem evangelizadora da Legenda Aurea de Jacopo de Varazze. São Paulo, 1998. Tese (Doutorado em História) - Faculdade de Filosofia, Letras e Ciências Humanas, Universidade de São Paulo, São Paulo. 1998.

${ }_{149}$ Luiz Gonzaga Teixeira, Topologia da mentalidade medieval: reflexões. São Paulo, 1999. Tese (Doutorado em História) - Faculdade de Filosofia, Letras e Ciências Humanas, Universidade de São Paulo, São Paulo. 1999.

${ }^{150}$ Heloisa Guaracy Machado, Da visão teológico-antropocêntrica nas cantigas de Santa Maria: um estudo sobre a concepção medieval e cristã da história. São Paulo, 2002. Tese (Doutorado em História) Faculdade de Filosofia, Letras e Ciências Humanas, Universidade de São Paulo, São Paulo. 2002.
} 
um eixo condutor de uma história universal, marcado por um caráter teológico e antropocêntrico, que alinhava os diversos conteúdos daquela obra e que dirigia o projeto político-cultural e exemplar-didático de Afonso X. Essa ideologia, fundamentada no maravilhoso cristão, é espelhada na narração dos milagres da Virgem e traz para a esfera do discurso as estruturas mentais fundamentais - o belicismo, o simbolismo e o contratualismo - que guiavam as relações do homem com os planos natural, transcendental e social, que estavam intimamente ligados. O conteúdo edificante e moralizante dos milagres de Santa Maria e dos louvores a ela endereçados dava à história o caráter de uma prolongada e difícil luta entre o Bem e o Mal, tendo em vista o modelo ideal de perfeição da civilização cristã e a construção, na Terra, da Cidade de Deus. Desta forma, Heloísa Machado examina determinados signos contidos nas Cantigas procurando em cada capítulo apresenta as principais categorias daquela visão bíblica da história, ao mesmo tempo terrena e sagrada, atualizadas pelo contexto político de Castela na segunda metade do século XIII.

Flávio de Campos ${ }^{151}$, professor da USP, defendeu em 2000 a tese $A$ escrita e a conversação honesta sobre a história de Portugal: as "Tardes do Verão" do frei Jerônimo Baía - uma edição atualizada e anotada que versa sobre a transcrição anotada e atualizada do manuscrito autógrafo Tardes de Verão e Conversação Honesta de Vária História escrito, a partir de 1667, pelo frei Jerônimo Baía. Tal obra contém vários gêneros e é definida como uma epopéia em prosa. As suas características retóricas e dialéticas são percebidas como modelares das práticas de comportamento e de convívio dos membros da sociedade cortesã.

Mário Jorge da Motta Bastos $^{152}$, professor de História Medieval da Universidade Federal Fluminense, onde orienta dissertações e teses relacionadas à idade média, defendeu, em 2002, a tese Religião e hegemonia aristocrática na Península Ibérica (séculos $I V$-VIII). O estudo examina as ligações entre a propagação do cristianismo e a afirmação da hegemonia da aristocracia no processo de formação do regime senhorial

\footnotetext{
${ }^{151}$ Flávio de Campos, A escrita e a conversação honesta sobre a história de Portugal: as "Tardes do Verão" do frei Jerônimo Baía - uma edição atualizada e anotada. São Paulo, 2000. Tese (Doutorado em História) - Faculdade de Filosofia, Letras e Ciências Humanas, Universidade de São Paulo, São Paulo. 2000.

${ }^{152}$ Mario Jorge da Motta Bastos, Religião e hegemonia aristocrática na Península Ibérica (séculos IVVIII). São Paulo, 2002. Tese (Doutorado em História) - Faculdade de Filosofia, Letras e Ciências Humanas, Universidade de São Paulo, São Paulo. 2002.
} 
entre os séculos IV e VIII na Península Ibérica. Para o historiador, é fundamental para caracterizar tal processo a ligação entre religião, cultura e relações sociais de produção em desenvolvimento no período, uma vez que, a partir dessa articulação, ele trata das questões que dizem respeito à conversão e à preservação de práticas e crenças estranhas ao cristianismo, geradas no âmbito das relações de dominação e resistência. A íntima vinculação existente entre a visão de mundo - das relações estabelecidas pelos homens entre si e com o meio natural - propagada pelo cristianismo e a afirmação da preponderância da aristocracia na época e na sociedade trabalhadas é percebida através do estudo de diversas fontes tais como, por exemplo, a hagiografia, a liturgia e a legislação régia.

A última tese que Franco Júnior orientou foi Um monge no divã. $O$ adolescer de Guibert de Nogent (1055-1125?): uma análise histórico-psicanalítica, defendida por Levinsky ${ }^{153}$ em 2004. Neste trabalho, que relaciona história e psicologia, Levinsky, a partir do estudo de um caso, o adolescer do monge Guibert de Nogent, procura estabelecer considerações gerais sobre o adolescer no período medieval. Na verdade, os seus dois objetivos principais são definir a adolescência como uma fase intrínseca ao desenvolvimento dos seres humanos - tal fase deve ser considerada a partir da construção da identidade adulta e da sua relação com a cultura - e desenvolver, através da relação histórico-psicanalítica, uma metodologia que possa ajudar na compreensão da formação do sujeito psíquico em suas relações com os fatos e processos históricos e que não despreze o coletivo e o individual, a cultura e o homem.

Doutorando-se em 2002 em História Medieval pela Université Lumière Lyon 2, na França, com a tese Reges pro publicis utilitatibus. Le problème de la légitimité royale de Clovis à Clotaire II (fin $V^{e}$ - début VII siècle) ${ }^{154}$, o professor Marcelo Cândido da Silva orientou na USP, onde leciona, as dissertações de Pereira e de Amaral, que foram defendidas em 2007. Em A representação do espaço urbano na hagiografia medieval franciscana (Compilatio assisiensis e Memoriale in desiderio animae): perspectivas de

\footnotetext{
${ }^{153}$ David Léo Levisky, Um monge no divã. O adolescer de Guibert de Nogent (1055-1125?): uma análise histórico-psicanalítica. São Paulo, 2004. Tese (Doutorado em História) - Faculdade de Filosofia, Letras e Ciências Humanas, Universidade de São Paulo, São Paulo. 2004.

${ }^{154} \mathrm{Cf}$. currículo Lattes. Disponível em <http://buscatextual.cnpq.br/buscatextual/index.jsp $>$ Acesso em: 29 janeiro 2008.
} 
uma politica social mendicante ${ }^{155}$, Pereira, baseado nas obras Compilatio assisiensis e Memoriale in desiderio animae, compilações hagiográficas do século XII sobre a vida de São Francisco de Assis, procura perceber as concepções sobre cidade dos hagiógrafos franciscanos e os elementos que eles usaram para formular tais concepções. Pereira analisa se aquelas idéias estão de acordo com um possível discurso franciscano direcionado para as práticas citadinas e também examina em que grau esses elementos se conjugaram na prática pastoral dos franciscanos nos espaços urbanos em que atuaram. Amaral, em Romance de Melusina: linhagem, penitência e poder ${ }^{156}$, tem como objetivo estudar o Romance de Melusina através de uma visão histórica que percebe que elementos como, por exemplo, a guerra e a justiça evocam o contexto de sua produção. Ao mesmo tempo, a historiadora não abandona as estratégias textuais do autor, João d'Arras, na construção da história nem as particularidades do romance.

Orientado por Franco Júnior, conforme foi mencionado acima, Flávio de Campos, professor da USP, orientou a dissertação Entre a ermida e a cidade: solitários sociáveis e a produção do significado no século XII, de Castanho ${ }^{157}$. Ao analisar determinado poema do século XII do cônego de Chartres Paganus Bolotinus, Castanho identificou os homens contra os quais o cônego tinha escrito o poema. Assim, pôde elaborar considerações sobre o eremitismo medieval, indicando que representações e práticas não ortodoxas tenham existido entre os que se sentiram atraídos pelo eremitismo. Além disso, Castanho elaborou comentários teóricos sobre o trabalho do historiador, sobre níveis e dinâmicas culturais, levando em consideração suas ligações com a forma literária presente na fonte primária da pesquisa e com a sociedade analisada.

Na UNICAMP, destacam-se as pesquisas que foram realizadas sob a orientação de Neri de Barros Almeida, sobretudo, no que diz respeito aos trabalhos vinculados as hagiografias medievais, no entanto, embora se tenha as informações de outras pesquisas

\footnotetext{
155 André Luís Pereira, A representação do espaço urbano na hagiografia medieval franciscana (Compilatio assisiensis e Memoriale in desiderio animae): perspectivas de uma política social mendicante. São Paulo, 2007. Dissertação (Mestrado em História) - Faculdade de Filosofia, Letras e Ciências Humanas, Universidade de São Paulo, São Paulo. 2007.

${ }^{156}$ Flávia Aparecida Amaral Romance de Melusina: linhagem, penitência e poder. São Paulo, 2007. Dissertação (Mestrado em História) - Faculdade de Filosofia, Letras e Ciências Humanas, Universidade de São Paulo, São Paulo. 2007.

${ }^{157}$ Gabriel de Carvalho Godoy Castanho, Entre a ermida e a cidade: solitários sociáveis e a produção de significados no século XII. São Paulo, 2007. Dissertação (Mestrado em História) - Faculdade de Filosofia, Letras e Ciências Humanas, Universidade de São Paulo, São Paulo. 2007.
} 
empreendidas nessa instituição sob a orientação dessa pesquisadora, encontrou-se apenas uma dissertação disponível para consulta on-line. Trata-se da dissertação de Figuinha $^{158}$ cujo tema problematiza a relação entre ascetismo e poder episcopal em Santo Agostinho. O autor estudou essa relação na conjuntura da controvérsia donatista durante a primeira década do século $\mathrm{V}$. O autor avaliou os problemas causados por essa controvérsia ao bispo de Hipona. Problematizou-se também como os valores ascéticos foram usados nas campanhas anti-donatista ao mesmo tempo em que se organizava a igreja católica. Por último, demonstrou-se como houve um empenho para se desenvolver um modelo mais organizado de monasticismo, centrado na autoridade episcopal, para que fosse possível diminuir as tensões entre os monges ao redor do bispo de Hipona.

A produção historiográfica sobre a idade média na UnB teve início em 1997 quando, ao ser criado o curso de doutorado, houve a reorganização das linhas de pesquisa do programa, que, de duas áreas relacionadas à história do Brasil, passou a contar com três linhas temáticas de pesquisa. Desta forma, a partir daquele ano, houve a possibilidade de serem realizadas teses e dissertações sobre o medievo. Em relação à história medieval, atuam a professora Maria Eurydice de Barros Ribeiro, fundadora e coordenadora do Programa de Estudos Medievais (PEM) ${ }^{159}$, e o professor Celso Silva Fonseca, representante do Laboratório de Estudos Medievais.

A primeira dissertação em história medieval defendida na $\mathrm{UnB}^{160}$, A justiça e os deveres senhoriais na obra de Philippe de Beaumanoir "Costumes de Beauvaisis", foi elaborada por Resende ${ }^{161}$ em 1997 e orientada pela professora Maria Eurydice Ribeiro. No ano seguinte, essa professora orientou a dissertação, Laços de sangue, laços de fé,

\footnotetext{
158 Matheus Coutinho Figuinha, Ortodoxia e poder na África romana: Santo Agostinho, ascetas e donatistas entre finais do século IV e inicio do século V. Campinas. 2006. Dissertação (Mestrado em História) - Instituto de Filosofia e Ciências Humanas, Universidade de Campinas, 2006.

${ }^{159}$ Para maiores informações sobre esse programa de estudo, Cf. Disponível em: <www.pemdf.cjb.net>. Acesso em: 29 janeiro 2008.

${ }^{160}$ As referências das teses e dissertações em história defendidos na Universidade de Brasília encontramse disponíveis no site da pós-graduação em história dessa universidade. Disponível em: $<$ http://www.unb.br/ih/novo_portal/portal_his/pos_graduacao/arquivos/relacao de teses_e dissertacoes.p df> Acesso em: 29 janeiro 2008.

${ }^{161}$ Ana Catarina Zema de Rezende, A justiça e os deveres senhoriais na obra de Philippe de Beaumanoir “Costumes de Beauvaisis”. Brasília, 1997. Dissertação (Mestrado em História) - Departamento de História. Universidade de Brasília, Brasília. 1997.
} 
relações familiares e solidariedade no catarismo do século XIII, de Lima ${ }^{162}$ e, em 2000, sob sua supervisão, Soares de Deus ${ }^{163}$ produziu a dissertação Do Oriente vem o vento que os leva ao Ocidente: representações literárias e iconográficas do espaço na Baixa Idade Média. Em 2006, houve a defesa da última dissertação, A golpes de machado: as origens da monarquia Franca, de Eduardo Fabbro ${ }^{164}$, que foi orientado pelo professor Celso Fonseca.

No que diz respeito às teses, foram produzidas, em 2004, Arautos da paz e bem: os fransciscanos em Portugal (1214 - 1336) de Mendes ${ }^{165}$ e, em 2005, A forma do mundo: o programa iconográfico do mapa de Hereford (século XIII) de Soares de Deus ${ }^{166}$. Ambas foram orientadas pela professora Maria Eurydice.

Dos seis trabalhos, apenas o resumo da dissertação de Fabbro consta na biblioteca digital de teses e dissertações da $\mathrm{UnB}^{167}$. Tal dissertação versa sobre a monarquia franca, que é vista a partir da sua penetração no mundo romano e da sua relevância política na ordenação do baixo império. Assim, o historiador percebe a monarquia germânica como fazendo parte, depois da queda do Império Romano do Ocidente, de um processo interno de reordenação desse império.

Na UFRGS, o professor José Rivair Macedo, único professor da área de História Medieval que atua na pós-graduação, orientou uma tese e nove dissertações sobre idade média ${ }^{168}$. Dentre as nove dissertações, constam, na biblioteca de teses e dissertações online dessa universidade os resumos de apenas quatro delas.

\footnotetext{
${ }^{162}$ Linda Joene Carvalho Granjense de Lima, Laços de sangue, laços de fé, relações familiares $e$ solidariedade no catarismo do século XIII. Brasília, 1998. Dissertação (Mestrado em História) Departamento de História. Universidade de Brasília, Brasília. 1998.

${ }_{163}$ Paulo Roberto Soares de Deus, Do Oriente vem o vento que os leva ao Ocidente: representações literárias e iconográficas do espaço na Baixa Idade Média. Brasília, 2000. Dissertação (Mestrado em História) - Departamento de História. Universidade de Brasília, Brasília. 2000.

${ }^{164}$ Eduardo Fabbro, A golpes de machado: as origens da monarquia franca. Brasília, 2006. Dissertação (Mestrado em História) - Departamento de História. Universidade de Brasília, Brasília. 2006.

${ }^{165}$ Terezinha Maria Duarte Mendes, Arautos da paz e bem: os fransciscanos em Portugal (1214 - 1336). Brasília, 2004. Tese (Doutorado em História) - Departamento de História. Universidade de Brasília, Brasília. 2004.

${ }^{166}$ Paul Roberto Soares de Deus, A forma do mundo: o programa iconográfico do mapa de Hereford (século XIII). Brasília, 20005. Tese (Doutorado em História) - Departamento de História. Universidade de Brasília, Brasília. 2005.

${ }_{167}$ Disponível em: < $<$ http://www.bce.unb.br/> Acesso em: 29 janeiro 2008.

${ }^{168}$ As referências e os resumos dos trabalhos em história medieval defendidos na Universidade Federal do Rio Grande do Sul encontram-se disponíveis em na biblioteca de teses e dissertações on-line dessa
} 
A tese orientada História do cerco de Lisboa: da representação factual à representação do imaginário de Peiruque ${ }^{169}$ foi aprovada em 2003.

Em 2001, orientou duas dissertações, Moço que tal faz, coração tem decerto pra mais": o ideal de cavalaria na obra de Fernão Lopes na construção do personagem Nuno Álvares Pereira de Nordin ${ }^{170}$ e O Orlando furioso e o ideal de "nobreza" na Ferrara renascentista de Ribeiro ${ }^{171}$. Outras duas dissertações foram defendidas em 2002: $A$ dama pé de cabra: o pacto feérico na Idade Média ibérica de Silveira ${ }^{172}$ e Traição $e$ poder: um estudo sobre o conceito de lesa-majestade em Castela medieval de Souza ${ }^{173}$. Em 2003, foi aprovada A categoria de espaço no Libro de las Cruzes de Afonso X, o Sábio de Mattos $^{174}$.

El rey que es formosura de Espanna: imagens do poder real na obra de Afonso $X$, o sábio (1221-1284) de Kleine ${ }^{175}$ e O próximo como o "outro": cristianismo e judaísmo na Corte imperial (Portugal, século XV) de Campos ${ }^{176}$ foram aprovadas em 2005. Kleine tem como objetivo estudar o aspecto propagandístico da obra de Afonso $\mathrm{X}$ levando em consideração a produção e a difusão da obra e a sua ligação com o projeto

universidade. Disponível em: <http://sabix.ufrgs.br/ALEPH/925LX9L15IH8N4G81SDQXAF4VEGJKP9I8EY6MUTNIHAV783I7B19695/file/start-0> Acesso em: 29 janeiro 2008.

${ }^{169}$ Elisabete Carvalho Peiruque, História do cerco de Lisboa: da representação factual à representação do imaginário. Porto Alegre, 2003. Teses (Doutorado em História) - Instituto de Filosofia e Ciências Humanas, Universidade Federal do Rio Grande do Sul, Porto Alegre. 2003.

${ }^{170}$ Nei Marcos Aibar Nordin, "Moço que tal faz, coração tem decerto pra mais": o ideal de cavalaria na obra de Fernão Lopes na construção do personagem Nuno Álvares Pereira. Porto Alegre, 2001. Dissertação (Mestrado em História) - Instituto de Filosofia e Ciências Humanas, Universidade Federal do Rio Grande do Sul, Porto Alegre. 2001.

${ }^{171}$ Marília de Azambuja Ribeiro, O Orlando furioso e o ideal de "nobreza" na Ferrara renascentista. Porto Alegre, 2001. Dissertação (Mestrado em História) - Instituto de Filosofia e Ciências Humanas, Universidade Federal do Rio Grande do Sul, Porto Alegre. 2001.

${ }^{172}$ Aline Dias da Silveira, A dama pé de cabra: o pacto feérico na Idade Média ibérica. Porto Alegre, 2002. Dissertação (Mestrado em História) - Instituto de Filosofia e Ciências Humanas, Universidade Federal do Rio Grande do Sul, Porto Alegre. 2002.

${ }^{173}$ Luciane Chiesa de Souza, Traição e poder: um estudo sobre o conceito de lesa-majestade em Castela medieval. Porto Alegre, 2002. Dissertação (Mestrado em História) - Instituto de Filosofia e Ciências Humanas, Universidade Federal do Rio Grande do Sul, Porto Alegre. 2002.

${ }^{174}$ Carlinda Maria Fischer Mattos, A categoria de espaço no Libro de las Cruzes de Afonso X, o Sábio. Porto Alegre, 2003. Dissertação (Mestrado em História) - Instituto de Filosofia e Ciências Humanas, Universidade Federal do Rio Grande do Sul, Porto Alegre. 2003.

${ }^{175}$ Marina Kleine, El rey que es formosura de Espanna: imagens do poder real na obra de Afonso X, o sábio (1221-1284). Porto Alegre, 2005. Dissertação (Mestrado em História) - Instituto de Filosofia e Ciências Humanas, Universidade Federal do Rio Grande do Sul, Porto Alegre. 2005.

${ }^{176}$ Rita de Cássia Boeira Campos, O próximo como o "outro": cristianismo e judaísmo na Corte imperial (Portugal, século XV). Porto Alegre, 2005. Dissertação (Mestrado em História) - Instituto de Filosofia e Ciências Humanas, Universidade Federal do Rio Grande do Sul, Porto Alegre. 2005. 
político de centralização empreendido pelo rei. Desta forma, para perceber o modo pelo qual o monarca revela o seu projeto político na sua obra, a historiadora examina as imagens do rex sapiens, rex iustus e do rex christianus. Campos estuda a representação dos judeus na obra do século XV, Corte Imperial, no contexto do término, na Península Ibérica, da coexistência inter-religiosa e da promulgação, em Portugal, das leis antisemitas.

Com a dissertação "Fémina inquieta y andariega": valores simbólicos da literatura cavaleiresca nos escritos da Santa Teresa de Jesus (1515-1582), Santos ${ }^{177}$ analisa a relação e a influência do ideal e o simbolismo cavaleiresco na obra de Santa Teresa d'Ávila através do estudo dos textos lidos pela santa e pelo seu contato com os livros de cavalaria.

Em 2007, Teixeira ${ }^{178}$ defendeu $A$ encruzilhada das idéias: aproximação entre a Legenda Áurea (Iacopo Varazze) e a Suma Teológica (Tomás de Aquino), dissertação na qual Teixeira analisa a cultura escolar e a pregação, dois eixos da atuação religiosa dos dominicanos na segunda metade do século XIII. O debate sobre os pecados e as virtudes e a questão do aspecto arcaico da Legenda Áurea de Iacopo Varazze foram abordados a partir da comparação desta obra com a Suma Teológica de Tomás de Aquino.

\footnotetext{
177 Luciana Lopes dos Santos, "Fémina inquieta y andariega": valores simbólicos da literatura cavaleiresca nos escritos da Santa Teresa de Jesus (1515-1582). Porto Alegre, 2006. Dissertação (Mestrado em História) - Instituto de Filosofia e Ciências Humanas, Universidade Federal do Rio Grande do Sul, Porto Alegre. 2006.

${ }^{178}$ Igor Salomão Teixeira, A encruzilhada das idéias: aproximação entre a "Legenda Áurea"(Iacopo Varazze) e a "Suma Teológica"(Tomás de Aquino). Porto Alegre, 2007. Dissertação (Mestrado em História) - Instituto de Filosofia e Ciências Humanas, Universidade Federal do Rio Grande do Sul, Porto Alegre. 2007.
} 